\title{
Synthetic nanoparticles for delivery of radioisotopes and radiosensitizers in cancer therapy
}

\author{
Jun Zhao ${ }^{1}$, Min Zhou ${ }^{2}$ and Chun $\mathrm{Li}^{i^{*}}$
}

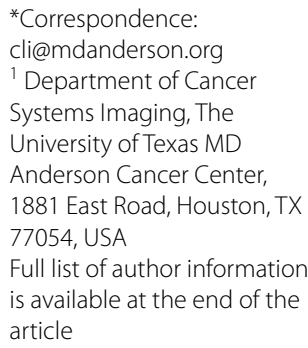

\begin{abstract}
Radiotherapy has been, and will continue to be, a critical modality to treat cancer. Since the discovery of radiation-induced cytotoxicity in the late 19th century, both external and internal radiation sources have provided tremendous benefits to extend the life of cancer patients. Despite the dramatic improvement of radiation techniques, however, one challenge persists to limit the anti-tumor efficacy of radiotherapy, which is to maximize the deposited dose in tumor while sparing the rest of the healthy vital organs. Nanomedicine has stepped into the spotlight of cancer diagnosis and therapy during the past decades. Nanoparticles can potentiate radiotherapy by specifically delivering radionuclides or radiosensitizers into tumors, therefore enhancing the efficacy while alleviating the toxicity of radiotherapy. This paper reviews recent advances in synthetic nanoparticles for radiotherapy and radiosensitization, with a focus on the enhancement of in vivo anti-tumor activities. We also provide a brief discussion on radiationassociated toxicities as this is an area that, up to date, has been largely missing in the literature and should be closely examined in future studies involving nanoparticlemediated radiosensitization.
\end{abstract}

Keywords: Nanoparticles, Radiotherapy, Radiosensitization, Radioisotopes

\section{Background}

The cytotoxic effects of ionizing radiation were first observed in 1895, when Wilhelm Röntgen intentionally subjected his finger to X-rays. Burns developed on the irradiated finger shortly after the exposure (Assmus 1995). Since then, ionizing radiation using both external and internal radiation sources has become one of the three pillars of anticancer treatments along with surgery and chemotherapy (Zoller et al. 2009). Nevertheless, contemporary radiation techniques are frequently challenged by the need to deposit as much energy as possible in tumor regions while minimizing the collateral damage to normal tissues. Indeed, toxic side-effects are often the dose-limiting factors in many cases, and can prevent the further escalation of radiation dose (DeNardo and Denardo 2006).

During the past several decades, nanomedicine has evolved into a promising player in cancer diagnosis and therapy (Retif et al. 2015; Li 2014). Nanoparticles can enhance the efficacy of radiotherapy through several mechanisms. The "targeted" nanoparticles, via

(c) The Author(s) 2016. This article is distributed under the terms of the Creative Commons Attribution 4.0 International License (http://creativecommons.org/licenses/by/4.0/), which permits unrestricted use, distribution, and reproduction in any medium, provided you give appropriate credit to the original author(s) and the source, provide a link to the Creative Commons license, and indicate if changes were made. 
either passive or active mechanisms, can selectively deliver radioisotopes into tumors (Eetezadi et al. 2015). Radiosensitizers can also be delivered to solid tumors through the use of nano-carriers to make tumors more vulnerable to external radiation. In addition, nanoparticles are ideal platforms to incorporate multiple functions and enable multimodality therapy. For example, multiple chemotherapy drugs can be loaded in the same nanoparticles to achieve a synergistic anti-tumor effect with radiotherapy. Imaging capabilities may also be integrated into nanoparticle design to provide image guidance (Phillips et al. 2014).

\section{External radiation sources}

External beam radiation treatment (EBRT) utilizes an external linear accelerator to generate high-energy X-rays, and delivers them to tumors. The photon energy of X-rays ranges from kilo- to mega-volts. Compared to the kilovoltage $\mathrm{X}$-rays, the megavoltage $\mathrm{X}$-rays can irradiate deep-seated tumors with minimal burning of superficial tissues, and therefore are widely used in patients (Wang et al. 2010). Along with the development of computer and electronic techniques within the past three decades, the way of delivering radiation beams has evolved significantly. The contemporary techniques include 3D-conformal radiotherapy, intensity-modulated radiotherapy (IMRT), and imageguided radiotherapy (DeNardo and Denardo 2006). Compared to conventional EBRT, IMRT delivers radiation dose with increased conformality, therefore limiting the dose exposure to normal organs (Samuelian et al. 2012). In a retrospective study by Samuelian et al. (Samuelian et al. 2012), $62 \%$ of patients experienced $\geq$ grade- 2 acute gastrointestinal toxicity after conventional EBRT, while only $32 \%$ of patients had the same sideeffects following IMRT $(p=0.006)$. Stereotactic body radiotherapy (SBRT) is another novel technique that can deliver a large radiation dose to tumor while keeping a plummet of dose at the peripheral of target regions. In this way, the volume of irradiated normal tissues is minimized. SBRT has been successfully used in treating lung, liver, spine, kidney, and pancreatic cancers (Pollom et al. 2015).

\section{Internal radiation sources}

Free metal ions are rarely injected by themselves due to their unfavorable biodistribution profiles. For example, free ${ }^{90} \mathrm{Y}$ ions tend to deposit in bone ( $50 \%$ of injected radioactivity) and cause bone toxicities (Ando et al. 1989). As a result, radioisotopes are often conjugated to carriers to achieve a tumor-specific accumulation. For instance, ${ }^{90} \mathrm{Y}$ and ${ }^{177} \mathrm{Lu}$ are frequently conjugated to tumor-specific peptides in the peptide receptor radionuclide therapy (PRRT) (van Essen et al. 2009). The anti-tumor efficacy of radioisotopes is affected by their tissue penetration: long-penetrating radioisotopes $\left(\right.$ e.g. $\left.{ }^{90} \mathrm{Y}\right)$ are more suitable for larger tumors, whereas short-ranged ones (e.g., ${ }^{177} \mathrm{Lu}$ ) can better treat micrometastases (Villard et al. 2012). In addition to $\beta$ emitters, $\alpha$ emitters and Auger emitters also have been evaluated in cancer therapy due to their promising energy transfer properties. For example, ${ }^{211}$ Astatine is a synthetic $\alpha$ emitter with a mean linear energy transfer value optimal for inducing DNA double-strand breaks (Langen et al. 2015). Auger electrons (Kassis 2004), on the other hand, are low-energy electrons generated by the radioisotopes that decay by electron capture and/or internal conversion (e.g., ${ }^{125}$ Iodine, ${ }^{123}$ Iodine, and ${ }^{77}$ Bromine). Such transitions of the inner-shell electrons result in a 
characteristic atomic X-ray photon, or low-energy and short-range mono-energetic electrons (collectively known as Auger electrons). Auger electrons have uniquely high values of linear energy transfer $(\sim 26 \mathrm{keV} / \mu \mathrm{m})$ within several cubic-nanometers from the site of decay. They can generate far more damage to DNA strands than those high-energy electrons. Several radioisotopes commonly used in radiotherapy are listed in Table 1.

\section{Radioisotope-loaded nanoparticles for internal radiation}

\section{Radiolabeling of nanoparticles via chelators}

Bifunctional chelators are normally needed to introduce radioisotopes to nanoparticles to achieve high radiolabeling stability. Since many excellent reviews have been published in this area (DeNardo and Denardo 2006; Liu 2008; Anderson and Welch 1999; Pohlman et al. 2006), only a brief discussion is presented in this section.

The chemical structures of several chelators are listed in Fig. 1. Diethylenetriaminepentaacetic acid (DTPA) exhibits high efficiency of radiolabeling under mild conditions, making it an attractive candidate to label nanoparticles sensitive to heat or $\mathrm{pH}$. However, DTPA chelation is kinetically labile, and may cause the dissociation of radioisotopes in vivo (Camera et al. 1994). As an example, Werner et al. (2011) developed biodegradable PLGA-lecithin-PEG core-shell nanoparticles that encapsulated paclitaxel in the core and chelated ${ }^{90} \mathrm{Y}$ on the surface via DTPA. Folic acid was conjugated to the surface of these nanoparticles as the targeting ligand. The resultant nanoparticles were $75 \pm 10 \mathrm{~nm}$ in size and $-35 \pm 5 \mathrm{mV}$ in surface charge. In an orthotopic ovarian cancer xenograft model, mice receiving the nanoparticles with both paclitaxel and ${ }^{90} \mathrm{Y}$ at a dose of $500 \mu \mathrm{g}$ nanoparticles/mouse ( $20 \mu \mathrm{g}$ paclitaxel and $1.85 \mathrm{MBq}{ }^{90} \mathrm{Y}$ per mouse) showed significant survival advantage over those receiving monotherapies.

Table 1 Properties of commonly used radioisotopes in radiotherapy

\begin{tabular}{|c|c|c|c|c|c|}
\hline Radionuclide & Half-life (Hour) & Emission type & Energy & $\begin{array}{l}\text { Range in tis- } \\
\text { sue }\end{array}$ & Ref. \\
\hline $\begin{array}{l}{ }^{111} \text { Indium } \\
\left({ }^{111} \ln \right)\end{array}$ & 67.9 & $\begin{array}{l}\text { Auger } \\
Y\end{array}$ & $\begin{array}{l}2.5-25 \mathrm{keV} \\
173-247 \mathrm{keV}\end{array}$ & $10 \mu \mathrm{m}$ & $\begin{array}{l}\text { (Giovacchini et al. } \\
\text { 2012) }\end{array}$ \\
\hline $\begin{array}{l}{ }^{177} \text { Lutetium } \\
\left({ }^{177} \mathrm{Lu}\right)\end{array}$ & 161.5 & $\begin{array}{l}\beta^{-} \\
\gamma\end{array}$ & $\begin{array}{l}E_{\max }=0.497 \mathrm{MeV} \\
E_{\text {mean }}=0.149 \mathrm{MeV} \\
113 \sim 321 \mathrm{keV}\end{array}$ & $2 \mathrm{~mm}$ & $\begin{array}{l}\text { (Giovacchini et al. } \\
\text { 2012; Nilsson et al. } \\
\text { 2011) }\end{array}$ \\
\hline $\begin{array}{l}{ }^{188} \text { Rhenium } \\
\left({ }^{188} \mathrm{Re}\right)\end{array}$ & 17 & $\begin{array}{l}\beta^{-} \\
\gamma\end{array}$ & $\begin{array}{l}2.12 \mathrm{MeV} \\
155 \mathrm{keV}\end{array}$ & $3.5 \mathrm{~mm}$ & $\begin{array}{l}\text { (Lin et al. 2014; Phae- } \\
\text { ton et al. 2016) }\end{array}$ \\
\hline $\begin{array}{l}{ }^{90} Y \text { ttrium } \\
\left({ }^{90} \mathrm{Y}\right)\end{array}$ & 64.1 & $\beta^{-}$ & $\begin{array}{l}E_{\text {max }}=2.28 \mathrm{MeV} \\
E_{\text {mean }}=0.935 \mathrm{MeV}\end{array}$ & $4.1-11.3 \mathrm{~mm}$ & $\begin{array}{l}\text { (Giovacchini et al. } \\
\text { 2012; Kennedy } \\
\text { 2014) }\end{array}$ \\
\hline
\end{tabular}

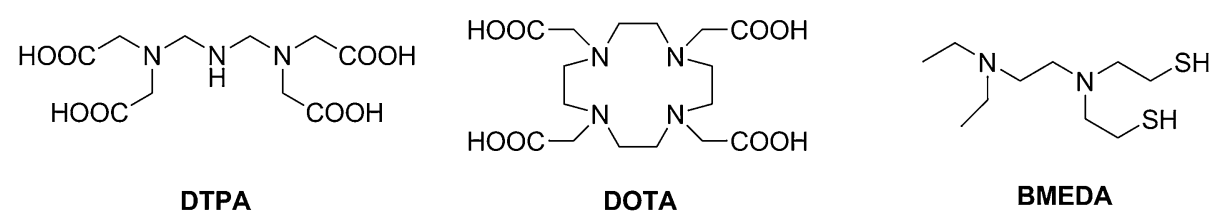

Fig. 1 Examples of radioisotope chelators (Kennedy 2014): diethylenetriaminepentaacetic acid (DTPA), 1,4,7,10-tetraazacyclododecane-1,4,7,10-tetraacetic acid (DOTA), and N,N-bis(2-mercaptoethyl) - $\mathrm{N}^{\prime}, \mathrm{N}^{\prime}$-diethylethylenediamine (BMEDA) 
1,4,7,10-Tetraazacyclododecane-1,4,7,10-tetraacetic acid (DOTA) is a macrocyclic chelator with kinetic inertness after chelation with radionuclides. However, the labeling yield can be affected by many parameters such as the DOTA concentration, $\mathrm{pH}$, reaction temperature, and heating time. Heating (e.g., $>50{ }^{\circ} \mathrm{C}$ ) is usually required for a high labeling efficiency. Under such conditions, the denaturing of bioactive antibodies or disruption of nanoparticles may be a concern ( $\mathrm{Li}$ et al. 1994). Wilson et al. (2012) conjugated ${ }^{177} \mathrm{Lu}^{3+}$ to the surface of tri-gadolinium nitride $\mathrm{C}_{80}$ endohedral metallofullerene nanoparticles $\left(\mathrm{Gd}_{3} \mathrm{~N} @ \mathrm{C}_{80}\right)$ via DOTA chelator. Previously, $\mathrm{Gd}_{3} \mathrm{~N} @ \mathrm{C}_{80}$ nanoparticles have been examined as highly efficient contrast agents for magnetic resonance imaging (Fatouros et al. 2006). The radiolabeling yield for ${ }^{177} \mathrm{Lu}^{3+}$ was $50 \%$ despite $12 \mathrm{~h}$ of reaction at $40{ }^{\circ} \mathrm{C}$. The anti-tumor activity of ${ }^{177} \mathrm{Lu}^{3+}$-labeled $\mathrm{Gd}_{3} \mathrm{~N} @ \mathrm{C}_{80}$ nanoparticles were evaluated in two orthotopic glioblastoma models (U87MG and GBM12) in mice after local-regional injection via convection-enhanced delivery (CED). During CED, a catheter is directly placed into tumor via stereotactic methods, followed by a slow injection of anti-cancer agents under a positive pressure gradient. Compared to the simple intratumoral injection, nanoparticles injected under the CED setting had a more uniform distribution inside the tumor. Doses of $0.25-1.35 \mathrm{MBq}$ significantly increased animal survival in both glioma xenograft models. The positive response was attributed to the short penetration distance $(0.7 \mathrm{~mm})$ of ${ }^{177} \mathrm{Lu}$, which deposited the majority of radiation energy on tumor cells.

$\mathrm{N}, \mathrm{N}$-Bis (2-mercaptoethyl) -N,'N'-diethylethylenediamine (BMEDA) is frequently used to chelate ${ }^{188} \operatorname{Re}$ (Bao et al. 2003; Chang et al. 2007), which shows potentials in cancer diagnosis and therapy because it emits both $\gamma$ rays $(155 \mathrm{keV})$ and $\beta$ particles $(2.12 \mathrm{MeV})$ (Deutsch et al. 1986). Huang et al. (2011) prepared ${ }^{188}$ Re-BMEDA-loaded liposomes with a radiolabeling efficiency of $88.0 \pm 2.8 \%$. The resulting liposomes were $80.3 \pm 1.1 \mathrm{~nm}$ in average diameter and $-1.44 \mathrm{mV}$ in $\zeta$ potential. Seventy-four percent of ${ }^{188} \mathrm{Re}$ was retained in liposomes after $72 \mathrm{~h}$ of incubation in serum. In an orthotopic rat glioma model, it was found that about $1.95 \%$ of injected dose was retained in each gram of tumor tissue $(1.95 \% \mathrm{ID} / \mathrm{g})$ at $24 \mathrm{~h}$ after intravenous injection. In comparison, the uptake in normal brain was less than $0.08 \% \mathrm{ID} / \mathrm{g}$. Lin et al. (2014) prepared a similar liposomal formulation to treat non-small cell lung cancer (NSCLC) in an orthotopic tumor model. Compared to the small-molecule complex ${ }^{188} \mathrm{Re}$-BMEDA, ${ }^{188} \mathrm{Re}$-liposomes exhibited higher blood retention and higher tumor uptake. A single injection of ${ }^{188} \mathrm{Re}$-liposomes at a dose of $23.7 \mathrm{MBq} /$ mouse effectively delayed tumor growth.

Other labeling techniques have also been used for introducing ${ }^{188} \mathrm{Re}$ to nanoparticles. Vanpouille-Box et al. (2011) prepared ${ }^{188}$ Re-labeled lipid nanocapsules using dithiobenzoate. In this technique, perrhenate ${ }^{188} \mathrm{ReO}_{4}{ }^{-}$ion was first reduced by a cocktail of $\mathrm{SnCl}_{2} /$ potassium oxalate/ascorbic acid/sodium gluconate, and then chelated by sodium dithiobenzoate to form a hydrophobic complex of ${ }^{188} \mathrm{Re}(\mathrm{III})\left(\mathrm{PhCS}_{3}\right)_{2}\left(\mathrm{PhCS}_{2}\right)$, abbreviated as ${ }^{188}$ Re-SSS (Lepareur et al. 2004). ${ }^{188}$ Re-SSS was then physically loaded into lipid nanocapsules, which were locally injected into 9L rat glioma in immunocompetent Fisher 344 rats by using CED technique at $2.8 \mathrm{MBq} /$ injection for two injections. The nanocapsules significantly prolonged the tumor retention of ${ }^{188} \mathrm{Re}$-SSS: more than $75 \% \mathrm{ID} / \mathrm{g}$ remained in brain at $96 \mathrm{~h}$ post injection. In contrast, $70 \%$ of injected ${ }^{188} \mathrm{ReO}_{4}{ }^{-}$ had been cleared from the body during the same time period. A promising cure rate of 
$83 \%$ was observed using an optimized treatment schedule. It is interested to note that

${ }^{188}$ Re-SSS-loaded lipid nanocapsules also suppress the growth of secondary tumors, suggesting a possible role of therapy-induced anti-tumor immune response.

The naturally existent porphyrins have exceptionally high affinity with metal ions and display intrinsic fluorescence (Smith and Gouterman 1968; Bases et al. 1958). Liu et al. (2013) labeled ${ }^{64} \mathrm{Cu}$ to a porphyrin-based liposome $\left({ }^{64} \mathrm{Cu}\right.$-porphysomes $)$ to delineate prostate tumors in orthotopic models by using positron emission tomography (PET). At $24 \mathrm{~h}$ after injection, the tumor uptake was $6.83 \pm 1.08 \% \mathrm{ID} / \mathrm{g}$ in PC-3 and $4.81 \pm 2.06 \%$ ID/g in 22RV1 prostate tumors in mice. Notably, micro-metastases as small as $1.4 \mathrm{~mm}$ were detected in bone. Since tumors at this size have limited angiogenic blood vessels, tumor uptake in small metastatic lesions may be facilitated by mechanisms other than the classical enhanced permeability and retention effect. Substitution of ${ }^{64} \mathrm{Cu}$ with therapeutic radioisotopes may render this class of nanoparticles suitable nano-carriers for treatment of micro-metastatic lesions.

\section{Chelator-free radiolabeling of nanoparticles}

Although it has been extensively used at both preclinical and clinical stages, chelatorbased radiolabeling still faces some limitations. There is no single chelator that binds to all isotopes with thermodynamic and kinetic stability. In many cases, the optimal chelator for an isotope needs to be empirically determined. Moreover, the in vivo stability of chelation can be compromised by endogenous protein trans-chelation, leading to the dissociation of isotopes from nanoparticles (Boswell et al. 2004).

We are among the first to introduce the concept of chelator-free radioactive nanoparticles taking advantage of radioisotopes and their non-radioactive isotopes of the same element as integral components of nanoparticles. This is exemplified by the synthesis of chelator-free ${ }^{64} \mathrm{Cu}$-doped copper sulfide nanoparticles $\left(\left[{ }^{64} \mathrm{Cu}\right]-\mathrm{CuS}\right.$ NPs) (Zhou et al. 2010). ${ }^{64} \mathrm{Cu}$ is a unique radioisotope suitable for both PET imaging and radiotherapy, because it emits $0.653 \mathrm{MeV}$ positron (17.8\%) and $0.579 \mathrm{MeV}$ beta particles $(38.4 \%)$ at a half-life of $12.7 \mathrm{~h}$. We have synthesized highly stable $\left[{ }^{64} \mathrm{Cu}\right]-\mathrm{CuS}$ NPs with high radiochemical yield (Zhou et al. 2010). These nanoparticles were $11.7 \mathrm{~nm}$ in size with citrate coating, and $31.6 \mathrm{~nm}$ with polyethylene glycol (PEG) coating, and displayed strong absorption of near-infrared light. PET/CT imaging clearly delineated the U87 glioma xenograft at $24 \mathrm{~h}$ post injection, with a tumor uptake value of $7.6 \pm 1.4 \% \mathrm{ID} / \mathrm{g}$ (Fig. 2). In subsequent studies, we demonstrated that PEG- $\left[{ }^{64} \mathrm{Cu}\right]-\mathrm{CuS}$ could be used to treat anaplastic thyroid cancer (Zhou et al. 2015a). Intratumoral injection of PEG- $\left[{ }^{64} \mathrm{Cu}\right]-\mathrm{CuS}$ at 7.4 MBq/mouse significantly delayed tumor growth compared to the non-treatment control $(p<0.0053)$, while no significant systemic toxicity was observed.

Black et al. (2014) added $\mathrm{H}^{198} \mathrm{AuCl}_{4}$ to the starting materials and directly incorporated ${ }^{198} \mathrm{Au}$ into the crystal lattice of Au nanostructures. The specific activity was tuned by changing the ration of $\mathrm{H}^{198} \mathrm{AuCl}_{4}$ to $\mathrm{HAuCl}_{4}$. The $\gamma$ emission from ${ }^{198} \mathrm{Au}$ enabled singlephoton emission computed tomography (SPECT), while the $\beta$ emission produced luminescence imaging via Cerenkov radiation.

Later work extended the concept of chelator-free radiolabeling to nanoparticles with radioisotopes that are not part of the building components of the nanoparticle. For example, Shaffer et al. (2015) reported silica nanoparticles for a generalized immobilization of 


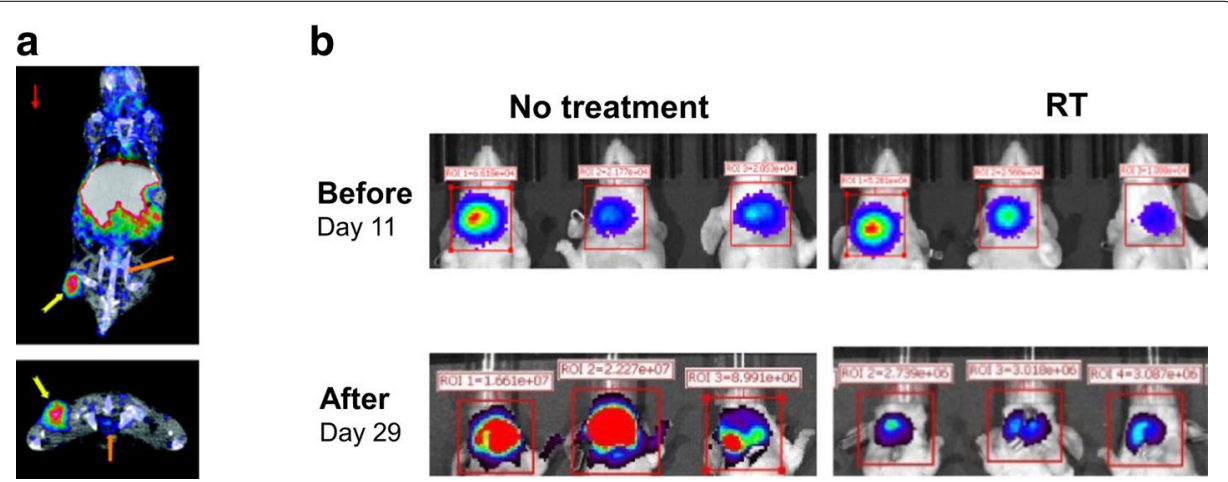

Fig. $2\left[{ }^{64} \mathrm{Cu}\right]-\mathrm{CUS}$ nanoparticles were used for both PET imaging (a) and radiotherapy (b). [reused with permission from references (Zhou et al. 2010, 2015a)]

radionuclides, including ${ }^{89} \mathrm{Zr},{ }^{68} \mathrm{Ga},{ }^{111} \mathrm{In},{ }^{90} \mathrm{Y},{ }^{177} \mathrm{Lu}$, and ${ }^{64} \mathrm{Cu}$. The radionuclides were bound by the oxygen atoms of the silica lattice. Radiolabeling was performed in a range of $\mathrm{pH}$ values $(\mathrm{pH}=5.7-8.8)$ at $70{ }^{\circ} \mathrm{C}$ for $15 \mathrm{~min}$, to give an efficiency $>99 \%$ and a specificity of $3.7 \mathrm{TBq} / \mu \mathrm{mol}$. Radovic et al. (2015) absorbed ${ }^{90} \mathrm{Y}^{3+}$ ions onto the negatively charged surface of $\mathrm{Fe}_{3} \mathrm{O}_{4}$ nanoparticles, with a labeling yield $>99 \%$. However, 5-20\% of the ${ }^{90} \mathrm{Y}$ dissociated after 1 week. Liu et al. (2015) absorbed ${ }^{64} \mathrm{Cu}$ on the surface of $\mathrm{MoS}_{2}$ nanosheets through the high affinity between $\mathrm{Cu}$ and $\mathrm{S}$ ions; 70-85\% labeling efficiency was achieved by shaking at $37{ }^{\circ} \mathrm{C}$ for $1 \mathrm{~h}$. The labeling was stable ( $>85 \%$ retention) during serum incubation at $37^{\circ} \mathrm{C}$ for up to $48 \mathrm{~h}$. Chelator-free labeling of nanoparticles by surface absorption is in general less stable compared to labeling with radioisotopes to be integrated to the matrix of the nanoparticles.

Sun et al. (2014) prepared ${ }^{64} \mathrm{Cu}$-doped $\mathrm{CdSe} / \mathrm{ZnS}$ core/shell quantum dots via cation exchange reaction in organic phase. After $1 \mathrm{~h}$ of incubation at $60^{\circ} \mathrm{C}$, the labeling efficiency was almost $100 \%$ with a specific activity of $7.4 \mathrm{MBq} / \mathrm{mg}$ of quantum dots. The shape and size of quantum dots were preserved after radiolabeling. The labeling was highly stable during serum incubation at $37{ }^{\circ} \mathrm{C}$ for up to $48 \mathrm{~h}$. Notably, the encapsulated ${ }^{64} \mathrm{Cu}$ enabled the Cerenkov luminescence and irradiated the quantum dots to generate luminescence. A similar method was used by Guo et al. (2015) for the preparation of ${ }^{64} \mathrm{Cu}$-labeled $\mathrm{CuInS} / \mathrm{ZnS}$ quantum dots. In another study, Sun et al. (2014) prepared ${ }^{64} \mathrm{Cu}$-coated Au nanoparticles by reducing ${ }^{64} \mathrm{Cu}^{2+}$ with hydrazine in the presence of $\mathrm{Au}$ nanoparticles. The formed ${ }^{64} \mathrm{Cu}$ element deposited on Au surface to achieve a radiolabeling up to $100 \%$ efficiency. Various Au nanoparticles were successfully labeled without changes in morphology or size.

Chloramine $\mathrm{T}$ oxidation is a common method for radioiodination of antibodies (Yamada et al. 2000). During the reaction, iodide is first oxidized to iodine monochloride, which then reacts with aromatic rings to form an iodine-tagged aromatic ring. Chloramine $\mathrm{T}$ oxidation has been used to label PEG-coated graphene nanosheets (PEG-GNS). Yang et al. (2011) prepared ${ }^{125}$ I-PEG-GNS with a labeling efficiency between 50 and $60 \%$ and a specific activity of 7.4 MBq/mg of NGS. Less than $5 \%$ of ${ }^{125}$ I detached after 15 days of incubation at $37{ }^{\circ} \mathrm{C}$ in saline or serum. Chen et al. (2015) used ${ }^{131}$ I-labeled PEG-GNS for the radiation/photothermal therapy in a $4 \mathrm{~T} 1$ murine breast cancer model. The resultant ${ }^{131} \mathrm{I}$-PEG-GNS was $50 \mathrm{~nm}$ in size and $3 \mathrm{~nm}$ in height. A majority of nanoparticles 
were entrapped in liver and spleen (15-20 ID \%g ) with a tumor uptake value of 5\% ID/g at $48 \mathrm{~h}$ after intravenous injection at a dose of $100 \mathrm{mg} / \mathrm{kg}(7.4 \mathrm{MBq} / \mathrm{mouse})$. Radiotherapy reduced tumor volume by about $70 \%$ at 18 days after treatment, while the combination therapy eliminated tumor in 4 out of 5 mice. No significant toxicities were observed in terms of liver, spleen, hematological toxicities, or body weight loss.

Neutron-activated nanoparticles

${ }^{166} \mathrm{Ho}$ is an attractive radionuclide for radiotherapy by emitting both gamma photons $(81 \mathrm{keV}, 6.6 \%)$ and high-energy $\beta$ particles (maximum energy at $1.84 \mathrm{MeV}$ ) at a half-life of $26.8 \mathrm{~h}$. It also provides contrast to CT and MRI due to its high attenuation coefficient and paramagnetic properties, respectively (Seevinck et al. 2007). ${ }^{166} \mathrm{Ho}$-labeled nanoparticles can be prepared through the neutron activation of the stable isotope ${ }^{165} \mathrm{Ho}$. The yield of ${ }^{166} \mathrm{Ho}$ conversion is proportional to the duration of neutron activation. Di Pasqua et al. (Di Pasqua et al. 2013) doped MCM-41-type mesoporous silica nanoparticles (MSN) with ${ }^{165} \mathrm{Ho}(\mathrm{AcAc})_{3}$, which was then converted to ${ }^{166} \mathrm{Ho}$ by neutron activation. The resultant ${ }^{166} \mathrm{Ho}-\mathrm{MSN}$ nanoparticles were $80-100 \mathrm{~nm}$ in size and $-49.2 \pm 6.0 \mathrm{mV}$ in surface charge, with a specific activity of $12 \mathrm{MBq} / \mathrm{mg} .{ }^{166} \mathrm{Ho}-\mathrm{MSN}$ was evaluated in an orthotopic SKOV3 ovarian cancer xenograft model by intraperitoneal injection. The tumor uptake (ID\%/g) was $32.8 \pm 8.1 \%$ at $24 \mathrm{~h}$ post injection, and reached $81 \pm 7.5 \%$ 1 week after. It should be noted that the tumor uptake value reported here was remarkably high compared to many other radioisotope-labeled nanoparticles. However, no explanation was given for the underlying tumor-homing mechanism, which may be in part attributed to the intraperitoneal injection route. In terms of anti-tumor efficacy, one injection of $4 \mathrm{MBq}{ }^{166} \mathrm{Ho}-\mathrm{MSN}$ reduced the tumor metabolism activity by $50 \%$ compared to control. Ninety-seven percent of the treated mice were alive at 75 days post-treatment, which was significantly higher than the groups without treatment or receiving free

${ }^{166} \mathrm{Ho}$ alone. In a follow-up study, Munaweera et al. (2015) prepared ${ }^{165} \mathrm{Ho}$-doped garnet magnetic nanoparticles and loaded them with platinum-based radiosensitizers. The formed nanoparticles were $40.7 \pm 16.4 \mathrm{~nm}$ in length and $26.9 \pm 8.0 \mathrm{~nm}$ in width, with typical ferromagnetic behaviors. Up to $6.2 \%$ (by weight) of platinum was loaded, and the specific activity was $9.25 \mathrm{MBq} / \mathrm{mg}$.

\section{Biological considerations for radiotherapy}

\section{Administration routes of nanoparticles}

In preclinical studies, nanoparticles are commonly administered via intravenous or intratumoral injection. Compared to intravenous injection, intratumoral injection of nanoparticles can directly deposit large doses to tumor site, without the toxicity to other organs. The theoretical simulations by Sinha et al. (2015) suggested that intratumoral injection of AuNPs provided better radiosensitization effects than intravenous injection. However, intratumoral injection is considered as a local therapy and is not suitable for treating disseminated disease. Due to the presence of brain-blood barrier in brain tumors, convection-enhanced delivery (CED) can provide a more uniform intratumoral distribution of nanoparticles (Fatouros et al. 2006). For pulmonary malignancies, on the other hand, inhalation is a viable option (Muralidharan et al. 2015). For ovarian cancer, 
intraperitoneal injection is sometimes used to increase exposure of tumors to the radioactive nanoparticles in the abdomen cavity (Di Pasqua et al. 2013).

In addition to tissue distribution, the radiosensitization effects of nanoparticles depend on their concentration as well as distribution inside cells. McQuaid et al. (2016) studied the correlation between intracellular distribution of gold nanoparticles and the range of DNA-damaging electrons produced during radiation. Chithrani et al. (2010) showed that AuNPs of $50 \mathrm{~nm}$ in size were optimal for cellular uptake and therefore more potent than both larger and smaller AuNPs in terms of radiosensitization. It is known that AuNPs, under radiation, can generate secondary electrons and damage DNAs within $30 \mathrm{~nm}$ range (Zheng et al. 2008). Therefore, intranuclear AuNPs can better induce DNA damage than the cytoplasmic ones. Oh et al. (2011) examined the intracellular distribution of gold nanoparticles (AuNPs). Small AuNPs ( 2.4 $\mathrm{nm}$ ) localized in nucleus, while larger ones $(5.5-8.2 \mathrm{~nm})$ retained in the cytoplasm in a perinuclear manner. Zhang et al. (2012) compared the radiosensitization effect of PEG-coated AuNPs with sizes of 4.8, 12.1, 27.3 and $46.6 \mathrm{~nm}$. Transmission electron microscopy (TEM) studies found that 4.8- and 46.6-nm AuNPs formed large aggregates when taken by HeLa cells, while the 12.1- and 27.3-nm AuNPs had more uniform distribution. The in vivo biodistribution study revealed that the 12.1-nm AuNPs had the highest tumor uptake. Since the radiosensitization effect is favored by a high intratumoral concentration of AuNPs, the best radiosensitization effect was achieved by the 12.7-nm AuNPs. Rima et al. (2013) examined the intracellular delivery of sub- $5 \mathrm{~nm}$ gadolinium-based nanoparticles in head and neck squamous cell carcinoma cells. TEM images established that the nanoparticles were internalized via passive diffusion and micropinocytosis, while the latter led to a successful radiosensitization in cell culture. In a follow-up study, Stefancikova et al. (2014) revealed that the gadolinium-based nanoparticles co-localized with lysosomes in U87 cells and still provide radio-enhancement under gamma irradiation.

\section{In vivo dosimetry of nanoparticle-bound radionuclides}

The radiation energy absorbed by tumor or normal tissues is an important predictor to the biological responses in each tissue (Zoller et al. 2009). The absorbed dose, a quantification of such energy, is defined as the energy absorbed per unit mass of tissue (Sgouros 2005). In addition, the tissue responses are also affected by the rate of dose delivery, the type of radiation sources (e.g., $\alpha, \beta$, or Auger particles), the radiobiological characteristic of each tissue, as well as the treatment history of patients (Sgouros 2005). Since most nanoparticle-bound radionuclides are used inside the body, a brief introduction to the dosimetry of internal emitters will be discussed in this section.

Absorbed dose $(D)$ is the appropriate term of dosimetry in practice, defined as the energy $(E)$ absorbed by the tissue, divided by the tissue mass $(M)$ :

$$
D=\frac{E}{M}=\frac{\breve{A} \times \Delta \times \varphi}{M}=\breve{A} \times S ; \quad \text { where } S=\frac{\Delta \times \varphi}{M},
$$

where $E=$ number of radionuclide disintegrations in a defined volume $(\breve{A}) \times$ energy emitted per disintegration $(\Delta) \times$ fraction of energy absorbed by the tissue mass $(\varphi)$. The first term, $\breve{A}$, depends on the half-lives of radionuclides as well as their spatial and 
temporal distribution. In clinics, the radioactivity from the region of interest is recorded by imaging or sampling, and plotted into a curve against time. The integral of this activity-time curve give the value for $\breve{A}$. The second term, $\Delta$, is related to the emission type, and can be derived from standard dosimetry tables (Browne et al. 1986). The last term, $\varphi$, accounts for the fraction of energy absorbed in the target region that is emitted from the source tissue, and commonly denoted as $\varphi_{\text {target } \leftarrow \text { source }} \varphi$ is generally derived from Monte Carlo calculations (Snyder et al. 1969). In practice, $\Delta, \varphi$ and $M$ are combined into one parameter $S$, and the total absorbed dose $\left(D_{\mathrm{T}}\right)$ is the sum of doses contributed by different sources:

$$
D_{\mathrm{T}}=\breve{A}_{S 1} \times S_{\mathrm{T} \leftarrow S 1}+\breve{A}_{S 2} \times S_{\mathrm{T} \leftarrow S 2}+\breve{A}_{S 3} \times S_{\mathrm{T} \leftarrow S 3} \ldots
$$

The list of $S$ values can be found from pamphlets published by the Committee on Medical Internal Radiation. However, it should be noted that due to the irregular geometry of tumor, the $S$ values generated from the idealized tables may provide erratic information of absorbed doses. Advanced imaging techniques and mathematical simulations have been developed for more accurate estimation (Sgouros 2005).

\section{Radiation-induced toxicity in healthy organs}

Few studies report nanoparticle-mediated radiotoxicity to normal organs. Since nanoparticles are largely distributed to organs of the mononuclear phagocytic system or kidney, we will briefly discuss the general radiotoxicity of liver and kidney.

\section{Liver}

In general, the whole liver can be safely irradiated with up to 30-35 Gy (Lawrence et al. 1995). Higher doses may cause subacute toxicity at $4-8$ weeks post radiation, commonly known as the veno-occlusive disease (Fajardo and Colby 1980). It is characterized by congestions in the central portion of liver lobes due to the entrapped erythrocytes, as well as the obstructed sub-lobular veins by collagen fibers. Collagen proliferation may also obstruct some small portal veins toward the end period of subacute damage. Although liver could heal over time after radiation, the asymptomatic chronic injuries may still persist up to 6 years post radiation, such as the distorted structures and fibrosis of liver lobules and veins. Such chronic lesions may be associated with chronic radiation hepatitis in clinics (Lewin and Millis 1973).

\section{Kidney}

Radiation-induced kidney damage can be characterized into acute and chronic nephropathy. The acute symptoms, such as proteinuria, hypertension, heart failure, azotemia, and anemia, reflect the pathological changes in kidney including atrophy, tubulointerstitial scarring, mesangiolysis, and thrombotic microangiopathy. The chronic symptoms, on the other hand, are characterized by the loss of mass and functions in kidney (Moll et al. 2001; Behr et al. 1999). In a follow-up survey, Valkema et al. (2005) observed a sustained decline of creatinine clearance in patients for up to 5.4 years after receiving PRRT.

Kidney can be safely treated with 15-17 Gy of EBRT in 2-Gy fractions. In case of nanoparticle-bound radionuclides, however, the threshold dose may be significantly different; because, both clearance and re-absorption of radionuclides can occur in kidney. 
Although currently few studies discuss the renal toxicity caused by radiolabeled nanoparticles, the PRRT-induced kidney damages have been reported (Giovacchini et al. 2012; Vegt et al. 2010). For instance, Svensson et al. (2012) showed that proximal tubulars of nude mice can be damaged by ${ }^{177} \mathrm{Lu}$-DOTA-Tyr ${ }^{3}$-octreotate above $24 \mathrm{~Gy}$.

Figure 3 shows the trafficking of peptides and small molecules in kidney. It is known that molecules less than $1.8 \mathrm{~nm}$ are rapidly filtered through the glomerular membranes and enter the proximal tubules, while those larger than $4-6 \mathrm{~nm}$ are mostly retained in blood circulation (Vegt et al. 2010). The filtrate inside proximal tubules, however, can be re-absorbed into blood circulation via active or passive transport. Oligopeptides can be hydrolyzed at the brush border of proximal tubular cells, and re-absorbed by transporters. Large peptides or proteins, on the other hand, are mainly absorbed by receptormediated endocytosis (Christensen and Verroust 2002; de Jong et al. 2005). It should be noted that some radiolabeled metabolites cannot escape the lysosomes of tubular cells, and thus reside in kidney and potentially cause radiation toxicity.

Renal toxicities can be alleviated by reducing the absorbed doses. Uehara et al. (2007) incorporated a cleavable glycyL-lysine linker between ${ }^{188}$ Re and antibody fragments, which was cleaved at the brush border of proximal tubules. As a result, ${ }^{188} \mathrm{Re}$ was not absorbed along with the antibody. The re-absorption of proteins can be lowered by coinjecting other molecules, including lysine, arginine, poly-L-lysine, succinylated gelatin,

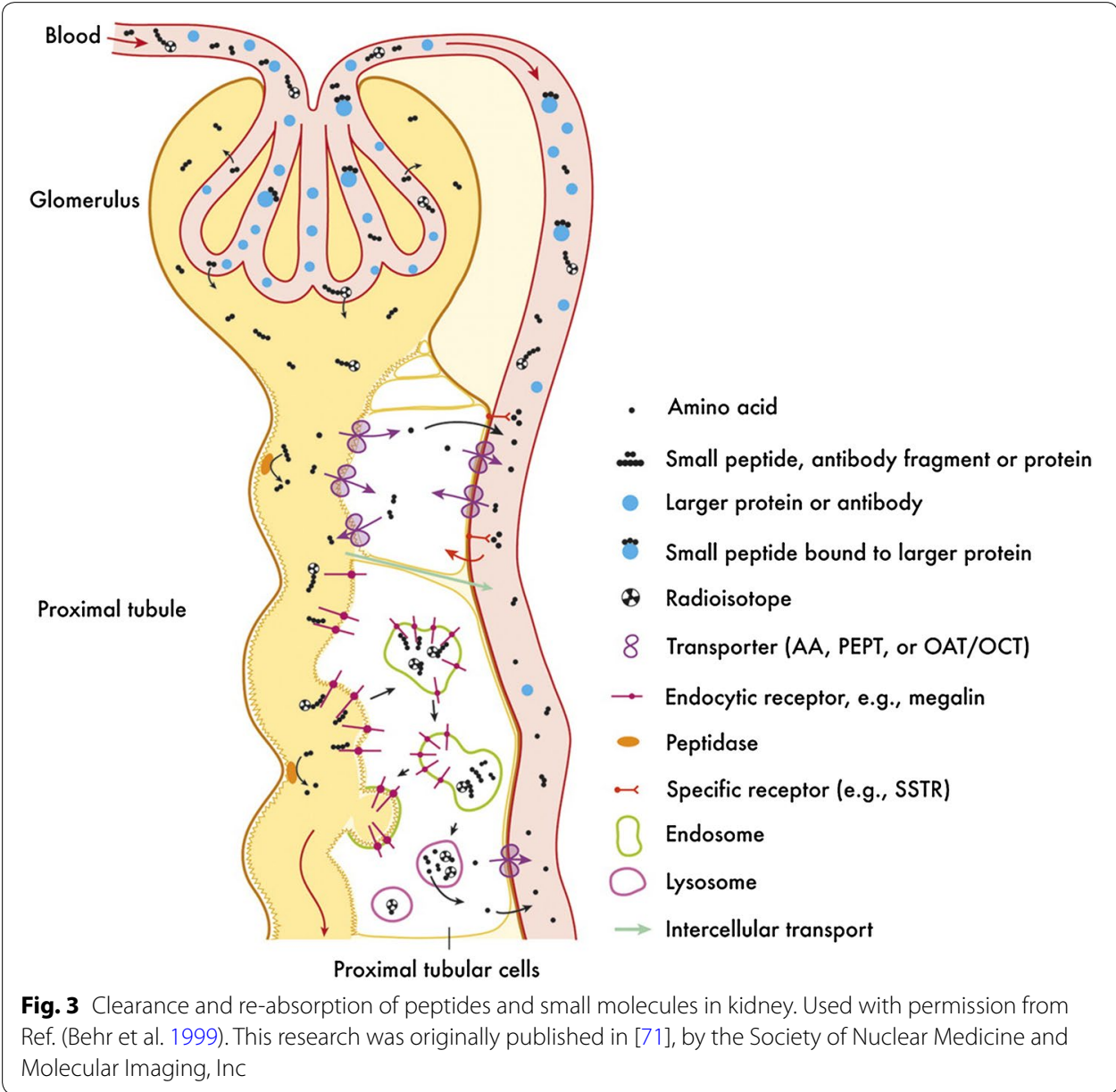


fractionated albumin, and albumin-derived peptide (Pimm and Gribben 1994). Another method is to inhibit the receptor-mediated endocytosis. For example, the renal uptake of

${ }^{111}$ In-octreotide was reduced by probenecid, which inhibits ochratoxin A transport and multidrug resistance proteins (Stahl et al. 2007).

\section{Nanoparticles for radiosensitization}

Despite the improvement in imaging and radiation sources, it is still a great challenge to confine the curative dose of radiation within tumor tissue while sparing the adjacent normal tissues. In many cases, the radio-toxicities to non-tumor tissues remain the dose-limiting factors. Therefore, it is of great benefit to increase the sensitivity of tumor cells to radiation, so that lower radiation doses can be used to eradicate tumor. Up to date, a plethora of radiosensitizers have been developed and evaluated based on different mechanisms, such as enhancement of dose, generation of radical oxygen species (ROS), and alteration of biological responses to radiation. A brief discussion of nanoparticles equipped with radiosensitization capabilities are presented as follows.

\section{Dose enhancement using high atomic number $(Z)$ materials}

Dose enhancement during radiotherapy was pioneered by Matsudaira et al. (1980), where iodine $(\mathrm{Z}=53)$ was found to increase the absorbed dose of X-rays in cell culture. Since then, the dose enhancement has been extended to various metal elements, including gold ( $\mathrm{Au}, \mathrm{Z}=79$ ) (Schuemann et al. 2016), gadolinium ( $\mathrm{Gd}, \mathrm{Z}=64$ ), platinum (Pt, $\mathrm{Z}=78$ ), and bismuth ( $\mathrm{Bi}, \mathrm{Z}=83$ ) (Chithrani et al. 2010; Kamiar et al. 2013; Jeremic et al. 2013; Alqathami et al. 2013; Yao et al. 2014; Ma et al. 2015; Le Duc et al. 2011; Miladi et al. 2013; Kryza et al. 2011; Miladi et al. 2015; Porcel et al. 2010; Usami et al. 2007, 2008). Notably, Gd-based nanoparticles presented both diagnostic and therapeutic potentials, since Gd also provides MRI contrast (Le Duc et al. 2011). Classical models have attributed the radiosensitization to the physical dose enhancement arising from the keV electrons. However, biological and chemical changes may also occur that subsequently increase the sensitivity of cells or tissues to radiation. The actual biological effects may come from both perspectives (Subiel et al. 2016).

Extensive studies have focused on exploring the underlying mechanisms of radiosensitization via high-Z metals (Porcel et al. 2010). An excellent overview was presented by Hainfeld et al. in their report of AuNP-enabled radiosensitization (Hainfeld et al. 2008). In general, high- $\mathrm{Z}$ atoms have large cross sections to absorb radiation energy, after which secondary radiations can be generated to cause damages in nearby DNA molecules. Such secondary radiations include short-range low-energy electrons, Auger electrons, photoelectrons, and characteristic X-rays (Jeremic et al. 2013). The ranges of such secondary electrons in tissue vary from about $10 \mathrm{~nm}$ for the Auger electrons, to $100 \mu \mathrm{m}$ for the photoelectrons, and as far as several centimeters for the fluorescence photons (Hainfeld et al. 2008). Using gold as an example, the dose enhancement is restricted to the vicinity of gold atoms. It is critical to have a uniform distribution of gold throughout the whole tumor, or more preferentially close to DNA molecules. As a result, nanoparticle formulations are advantageous due to their ability to selectively deposit in tumor and to be internalized by tumor cells (Oh et al. 2011). Indeed, micrometric gold nanoparticles were restricted to the site of injection, instead of distributing throughout the 
tumor (Herold et al. 2000). It should be noted, however, majority of the nanoparticles reside within cytoplasm unless a specific nuclei-delivery is incorporated in the design of nanoparticles. It remains of question whether DNA damage can be induced by the secondary electrons produced from cytoplasmic nanoparticles. On the other hand, the dose enhancement factor (DEF) by AuNPs varies with radiation sources. A simulation study by Lin et al. (2015) calculated that $43 \%$ additional dose was produced by AuNPs for $250 \mathrm{keV}$ photons, $1 \%$ for $6 \mathrm{MeV}$ photons, and only $0.1 \%$ for protons. Rahman et al. (2014) irradiated 1.9-nm AuNPs with X-rays from 30 to $100 \mathrm{keV}$. The 40-keV X-ray had the highest DEF at 3.47, while both lower and higher energy X-rays had lower DEFs. A probable explanation is that low-energy photons can be absorbed by the $\mathrm{K}$ or $\mathrm{L}$ shell electrons of $\mathrm{Au}$. The resultant secondary Auger electrons emission then causes further damage to DNAs. In contrast, high-energy photons tend to have Campton scattering without producing Auger electrons (Kobayashi et al. 2010).

Hainfeld et al. $(2004,2006,2008)$ first examined the in vivo radiosensitization effect of 1.9-nm AuNP in a murine EMT-6 mammary tumor model. Mice were injected with a dose of $1.35 \mathrm{gAu} / \mathrm{kg}$, which resulted in a $4.9 \pm 0.6 \% \mathrm{ID} / \mathrm{g}$ tumor uptake at $5 \mathrm{~min}$ post injection. For radiation therapy, $30 \mathrm{~Gy}$ of $250 \mathrm{kV}$ X-ray was applied to the tumor region at 2 min post injection of AuNP. Most tumors were undetectable at 1 month after treatment with AuNP plus radiation, while the monotherapy groups only delayed tumor growth. Long-term survival studies (up to 1 year) also showed a benefit of the combination therapy as well as a response dependent on the dose of gold (Hainfeld et al. 2004). While many studies have proven the radiosensitization effects of AuNPs in both cell culture and animal models, the long-term body retention of AuNPs remains a concern despite that AuNPs are often considered safe and bio-inert (Zelasko-Leon et al. 2015). To minimize such potential chronic toxicity, several clearable formulations of AuNPs were developed. Zhang et al. (2015) prepared 2.8-nm glutathione-protected AuNPs for radiosensitization. The combination therapy of AuNPs and $5 \mathrm{~Gy}$ of ${ }^{137} \mathrm{Cs}$ radiation completely inhibited the growth of U14 brain tumor xenograft. Notably, the ultrasmall 2.8nm AuNPs had minimal uptake in the RES organs such as liver and spleen, and were cleared via kidney. The body clearance of AuNPs was completed at 28 days after injection. The same group also studied the sub 2-nm glutathione-protected AuNPs (Zhang et al. 2014), showing similar radiosensitization effects. In this study, however, significant liver uptake ( $\sim 30 \% \mathrm{ID} / \mathrm{g})$ was found at $24 \mathrm{~h}$ post injection. Such discrepancy may arise from the fact that fluorescence dye Cy5 was conjugated to AuNPs and used as tracer for uptake studies. The dissociation and subsequent retention of Cy5 in liver may cause a falsely high uptake of AuNPs. Further studies are required to clarify such an issue.

Other metal elements were also tested for dose enhancement. Gadolinium-based (Gd, $\mathrm{Z}=64$ ) ultrasmall nanoparticles (GBNs) have been evaluated for radiosensitization by a group of French researchers (Le Duc et al. 2011; Miladi et al. 2013; Kryza et al. 2011; Miladi et al. 2015). The GBNs are composed of a $\mathrm{Gd}_{2} \mathrm{O}_{3}$ core surrounded by a silica shell, with a hydrodynamic diameter of $3.8 \pm 0.1 \mathrm{~nm}$. Biodistribution study found a high rate of renal clearance after the intravenous injection of GBNs. Over $95 \%$ of injected dose was eliminated within 18 days after injection, via both urine and feces. The small size also reduced the fenestration in organs of the mononuclear phagocytic system, showing a minimal uptake in liver (<0.5\% ID/g) (Kryza et al. 2011). Le Duc et al. (2011) evaluated 
the GBNs in a rat model bearing intracerebral 9L gliosarcoma along with microbeam radiotherapy. DTPA was coated to the surface of GBNs to chelate $\mathrm{Gd}^{3+}$ ions and subsequently provide MRI contrast. MRI delineated the tumor up to $45 \mathrm{~min}$ after intravenous injection of GBNs, with a tumor-to-tissue ratio of 60.4 being reached at $20 \mathrm{~min}$ post injection. Microbeam radiotherapy was applied to tumor at $20 \mathrm{~min}$ post injection, and the mean survival time was extended to 90 days, compared to 47 days for radiation-only control, and 19 days for non-treatment control. Miladi et al. (2015) examined the GBNs in several radio-resistant human head and neck squamous cell carcinoma models along with $250 \mathrm{keV}$ photon irradiation. The combination of GBNs and radiation overcame the radiation resistance in SQ20B stem-like cells, significantly delayed tumor growth with elevated late apoptosis and reduced cell proliferation. Sancey et al. (2014) reviewed in detail the evolution of Gd-based theranostic nanoparticles, which has recently been benchmarked as $A G u I X^{\circledR}$. It should be noted that high radiosensitization effects were reached even with a Gd concentration as low as $1 \mathrm{ppm}$ in tumor. Auger electrons were believed to be the main contributor for radiosensitization under such scenarios.

The radiosensitization of platinum-based nanoparticles has been explored (Porcel et al. 2010; Usami et al. 2005, 2007, 2008, 2010), especially in combination with fast atomic ions such as $\mathrm{Fe}^{26+}$ and $\mathrm{C}^{6+}$. Unlike photons and electrons, such heavy atoms with large cross sections interact with tissues on their trajectory tracks, and therefore are more efficient than conventional radiations (Dan et al. 2003; Mozumder 2003). Porcel et al. (2010) showed that both Pt ions and 3-nm Pt nanoparticles bound to DNA molecules, and increased the number of single-strand breaks and double-strand breaks during radiation. The enhancement ratios were between 1.37 and 2.17. Importantly, DNA damages were significantly alleviated by adding radical scavengers, indicating that radiationinduced water radicals were a prominent culprit of DNA damage (Usami et al. 2007). Since DNA is generally accepted as the main target of ionizing radiation in cells, the produced DNA damages may serve as a probe to quantify the radiation-enhancing effect of nanoparticles. Gel electrophoresis has been used to quantify the number of singleand double-strand breaks ex vitro (Usami et al. 2007), while many staining techniques are available to visualize the DNA breaks in cell culture or tissues (Mah et al. 2010; Zhu et al. 2014).

Bismuth ( $\mathrm{Bi}, \mathrm{Z}=83$ )-based nanoparticles have shown to induce above $80 \%$ enhancement of radiation dose while maintaining low toxicities (Alqathami et al. 2013). Yao et al. (2014) prepared $\mathrm{Bi}_{2} \mathrm{~S}_{3}$-loaded PLGA nanoparticles. The resultant nanoparticles were $754.6 \mathrm{~nm}$ in size and distributed to PC3 prostate xenograft tumor within $30 \mathrm{~min}$ of injection, although $80 \%$ of injected dose was fenestrated in liver. The combination therapy with 6-Gy radiation and $\mathrm{Bi}_{2} \mathrm{~S}_{3}$-PLGA inhibited tumor growth more effectively than monotherapy groups, along with the upregulation of apoptosis-related proteins, including p53, Bax, and Bcl-2. Ma et al. (2015) prepared $\mathrm{Bi}_{2} \mathrm{~S}_{3}$-embedded mesoporous silica nanoparticles (BMSNs) for radiosensitization. Hydrophobic $\mathrm{Bi}_{2} \mathrm{~S}_{3}$ nanoseeds of $2-3 \mathrm{~nm}$ in diameter were first prepared, followed by a sol-gel condensation of triethoxysilane, to form the mesoporous nanoparticles of $72.7 \mathrm{~nm}$ in size. BMSNs were used in combination with $1.85 \mathrm{MBq}$ interstitial ${ }^{32} \mathrm{P}$ irradiation to treat $\mathrm{PC} 3$ prostate xenograft tumor. Compared to monotherapies, the combination therapy effectively inhibited tumor growth and induced prominent apoptosis of tumor cells. 


\section{Generation of reactive oxygen species (ROS)}

Radiation-generated ROS is an important cytotoxic component for killing cancer cells (Allison et al. 2004). The cytotoxic ROS can also be generated via photodynamic therapy (PDT). PDT is an emerging non-invasive treatment that utilizes light-excitable photosensitizers to produce cytotoxic ROS upon photon illumination (O'Connor et al. 2009). Unlike many other chemotherapy drugs that need to enter cytoplasm or nucleus to function, the major target of ROS are lysosomes that belong in the endocytosis pathway of nanoparticles (Leamon and Low 1991). Therefore, endosome escape is not required for the ROS-generating nanoparticles to exert cell-killing effects. Once lysosomes are ruptured by ROS, cathepsin B or L are released to activate caspases, which in turn inactivates proteins that protect cells from apoptosis (de Castro et al. 2016). Conventional PDT has two drawbacks. First, the generation of ROS requires oxygen, and therefore has limited efficiency in the hypoxic tumor microenvironment (Vaupel et al. 2001). Second, traditional photosensitizers are excited by ultraviolet or visible lights that have limited tissue penetration (Allison et al. 2004).

Recently, semiconductor nanoparticles have been developed that can downconvert the $\mathrm{X}$-ray energy into ultraviolet/visible region, which can subsequently activate the nearby photosensitizers (Bulin et al. 2013). Zhang et al. (2015) prepared 33-nm cerium(III)doped $\mathrm{LiYF}_{4} @ \mathrm{SiO}_{2} @ \mathrm{ZnO}$ nanoparticles that can generate cytotoxic hydroxyl free radicals upon X-ray irradiation. The X-ray was downconverted to ultraviolet fluorescence in the cerium(III)-doped LiYF4 core, and further generated electron-hole $\left(\mathrm{e}^{-}-\mathrm{h}^{+}\right)$pairs in $\mathrm{ZnO}$. Highly reactive hydroxyl radicals were produced from the reaction between the hole $\left(\mathrm{h}^{+}\right)$and surrounding water. Since no oxygen was involved in the reaction, free radicals were generated in both normoxic and hypoxic conditions. Importantly, the inorganic photosensitizer was resistant to photobleaching during X-ray treatment. The combination therapy of the nanoparticle with 8-Gy X-ray radiation effectively inhibited the growth of HeLa xenograft tumor up to 15 days after treatment.

Auger effects may increase ROS generation upon X-ray irradiation (Kobayashi et al. 2010). He et al. (2015) prepared mesoporous silica nanoparticles loaded with selenocysteine (SeC@MSNs). The ROS generated by SeC@MSNs and 2-Gy X-ray via Auger effects was $202 \%$ of control. Extensive cell apoptosis was recorded, evidenced by the subG1 population in cell cycle analysis. The activation of apoptosis pathways, e.g., p53 and ATM/ATR, was also observed. In vivo anti-tumor efficacy in HeLa xenograft showed that combination group had the smallest tumor volume. In a similar study, Huang et al. (2014) conjugated bovine serum albumin with phenylbenzo (Assmus 1995; Zoller et al. 2009; Li 2014) selenadiazole derivatives. The resultant nanoparticles also generated ROS upon X-ray irradiation, and radiosensitized HeLa xenograft tumor. Alternatively, nanoparticles can catalyze the production of hydroxyl radicals in aqueous solution upon X-ray irradiation (Sicard-Roselli et al. 2014).

It is known that the efficacy of radiotherapy can be mitigated by the hypoxic tumor microenvironment (Vaupel et al. 1991). Prasad et al. (2014) prepared $\mathrm{MnO}_{2}$-bound albumin nanoparticles $\left(\mathrm{A}-\mathrm{MnO}_{2}\right)$ to re-oxygenate the tumor microenvironment. The hypoxic tumor microenvironment and the highly proliferating tumor cells, together, produce ROS, e.g., $\mathrm{H}_{2} \mathrm{O}_{2} . \mathrm{MnO}_{2}$ reacts with the $\mathrm{H}_{2} \mathrm{O}_{2}$ to produce $\mathrm{O}_{2}$. Within 7 min of intratumoral injection of $\mathrm{A}-\mathrm{MnO}_{2}$, the vascular saturated $\mathrm{O}_{2}$ increased by $45 \%$ compared 
to control. Immunohistochemical staining found decreased expression of both hypoxia markers HIF- $1 \alpha$ and VEGF in treated tumor. When combined with radiation, a significant inhibition of tumor growth was observed, along with elevated staining of DNA double-strand breaks.

\section{Re-distribution of cell cycles to radiosensitive G2/M phases}

While most radiosensitization experiments are conducted using keV-energy radiation sources, current clinical therapy has shifted toward higher energy $(\mathrm{MeV})$ sources in order to treat deep-seated tumor, as well as to reduce toxicity to skin (Jeremic et al. 2013). However, the DEF of AuNPs is only marginal, between 1.1 and 1.2, for $\mathrm{MeV}$ X-rays. Nevertheless, a series of studies were performed on the combination of $6 \mathrm{MeV}$ radiation and AuNPs of sizes between 13 and $55 \mathrm{~nm}$ (Liu et al. 2015; Li et al. 2015; Wang et al.2015). Although radiosensitization effects were still observed, the underlying mechanism was found not due to dose enhancement, but rather the re-distribution of cell cycles to the radiosensitive G2/M phases by AuNPs. Cyclin A, cyclin B1, cyclin E, and p53 are the critical mediators of AuNP-induced arrest of cell cycles (Roa et al. 2009). Liu et al. (2015) used EGFR-targeting hollow gold nanospheres to enhance the $\mathrm{MeV}$ radiation in cervical cancer. Uptake of hollow gold nanospheres induced cell arrest in $\mathrm{G} 2 / \mathrm{M}$ phase (38.4 vs.10.2\% in control), leading to increased cell apoptosis during radiation. In addition, the hollow gold nanospheres elevated the expression of pro-apoptotic regulator, which may also have contributed to the radiosensitization. Wang et al. (2015) combined thioglucose-modified AuNPs (16 or $49 \mathrm{~nm}$ ) with $6 \mathrm{MeV}$ X-ray irradiation for the treatment of MB-MDA-231 triple-negative breast cancer cells. Cell arrest in G2/M phases was observed in cells treated with AuNPs of both sizes. However, it is not clear how AuNPs caused cell arrest in G2/M phase, which remains to be studied. The 49-nm AuNPs had higher uptake in cancer cells, and subsequently had higher sensitive enhancement ratio (SER) at 1.86 than the $16-\mathrm{nm}$ ones (SER $=1.49)$.

Chemotherapy drugs constitute another category of cell cycle regulators (Russo et al. 2016; Li et al. 2016), among which paclitaxel is widely used to treat various types of cancer (Pazdur et al. 1993). Paclitaxel promotes the assembly of microtubules and inhibits their disassembly (Pazdur et al. 1993). Cells treated with paclitaxel are predominantly arrested in G2/M phases, and therefore have increased sensitivity to radiation (Creane et al. 1999). Due to its limited water solubility, paclitaxel has been formulated into many nanoformulations to increase its bioavailability. Our group developed a poly(L-glutamic acid)-conjugated paclitaxel (PG-paclitaxel) (Milas et al. 2003; Ke et al. 2001; Li et al. 2000; Li et al. 2000). In the OCA-1 ovarian cancer xenograft model, PG-paclitaxel enhanced the radiation response by a factor of 7.2-8.4 (Milas et al. 2003). Recently, Werner et al. (Werner et al. 2013) compared the radiosensitization of free paclitaxel and PG-paclitaxel in non-small cell lung cancer models. PG-paclitaxel had higher sensitizer enhancement ratio (SER) in both A549 cells (1.23 vs. 1.12 for paclitaxel) and H460 cells (1.12 vs. 1.03 for paclitaxel). When combined with 5 daily fractions of 3-Gy radiation, PG-paclitaxel led to significantly longer delay of tumor growth than paclitaxel in the H460 xenograft model $(p=0.008)$. Similarly, Jung et al. (2012) prepared paclitaxel-loaded polymeric nanoparticles to radiosensitize A549 xenograft model. The resultant nanoparticles were $39.4 \mathrm{~nm}$ in size and actively internalized by cancer cells. The volume of tumor treated by 
nanoparticle and radiation was only $38.9 \%$ of un-treated tumor. Currently, PG-paclitaxel is under development by CTI Biopharma as paclitaxel poliglumex in combination with cetuximab and radiotherapy, to treat patients with head and neck cancer (https://clinicaltrials.gov). The study is ongoing and its results are pending.

\section{Disruption of DNA damage repair}

Ionizing radiation creates DNA damages such as double-strand break, single-strand break, and altered bases (Gavande et al. 2016). The readers are referred to reference (Kavanagh et al. 2013) for a broader understanding of radiation-induced DNA damages. These DNA damages can be repaired via various pathways including non-homologous end joining, homology directed repair, base excision repair etc. Many protein regulators are involved, such as DNA-PK, DNA-ligases, Rad51, and ATM (Lord and Ashworth 2012). Many chemotherapy drugs can disrupt the DNA damage repair, and subsequently enhance radiotherapy (Wieringa et al. 2016). Several nanoparticle-based formulations for inhibition of DNA damage repair are discussed below.

Wang et al. (2015) prepared PLGA-based polymeric nanoparticles to encapsulate histone deacetylase inhibitors (HDACIs). HDACIs disrupt the repair of DNA double-strand breaks, and subsequently cause cell death (Chinnaiyan et al. 2005). However, the effect of HDACIs is reversible. A prolonged exposure to HDACIs is required to achieve successful tumor inhibition and radiosensitization (Lee et al. 2010). Wang et al. utilized the nanoformulations to achieve a controlled release of HDACIs in tumor, and therefore to extend the drug exposure. In vitro radiosensitization was confirmed via colony survival assays and immunostaining of $\gamma$-H2AX DSB foci. PC3 (prostate cancer) and SW620 (colon cancer) xenografts were treated with 3-Gy X-ray irradiation and the nanoparticles. Significantly slower tumor growth was observed in combination groups.

$\mathrm{Au}$ et al. (2015) prepared PEG-PLGA polymeric nanoparticles to encapsulate docetaxel and wortmannin. Docetaxel induces cell cycle arrest in G2/M phases, as well as increases ROS production (Rabi and Bishayee 2009). Wortmannin is a potent inhibitor for phosphoinositide 3-kinase (PI3-K), and disrupts the repair of DNA damages (Wipf and Halter 2005). The resultant nanoparticles were $36 \pm 6 \mathrm{~nm}$ in size. Up to $40 \%$ of injected nanoparticles accumulated in tumor, while liver trapped around $60 \%$ of injected dose. When combined with 8-Gy X-ray radiation, the mean survival of H460 tumorbearing mice was 33.2 days longer than non-treatment control, and 28 days longer than radiation-only group.

Recently, we have developed several cyclopamine-loaded nanoparticles for radiosensitization (You et al. 2015; Zhao et al. 2015). Cyclopamine is a potent inhibitor for sonic hedgehog signaling, and disrupts the repair of radiation-induced DNA damages. When testing pancreatic cancer cells, the cyclopamine-loaded polymeric micelles enhanced the radiation by a factor ranging from 1.5 to 1.8 along with the extended presence of $\gamma-\mathrm{H} 2 \mathrm{AX}$ foci (Zhao et al. 2015). We also evaluated the radiosensitization of cyclopamine-loaded lipid nanoparticles in a pancreatic cancer xenograft (Miapaca-2) and a $4 \mathrm{~T} 1$ breast cancer model. ${ }^{177} \mathrm{Lu}$-conjugated polymeric micelles were used as intratumoral radiation source. The combination therapy was more effective in tumor suppression than radiation monotherapy in both tumor models. 


\section{Combination with photothermal therapy}

It is well known that hollow gold nanostructures exhibited unique optical properties to absorb near-infrared light irradiation (Oldenburg et al. 1998), and transform its energy into heat (Liu et al. 2008). A myriad of nanoparticles with different chemical compositions and architectures have been developed during the past decades that exhibit photothermal conversion properties in the near-infrared region of light (Huang et al. 2008; Melancon et al. 2011; Song et al. 2015; Xiao et al. 2013).

The nanoparticle-mediated photothermal effects are confined to the close vicinity of nanoparticles, and therefore can minimize the damage to adjacent normal tissue. While the high-temperature thermal ablation results in acute cell necrosis, hyperthermia (40$46^{\circ} \mathrm{C}$ ) can induce cellular biochemical alterations that can synergize with radiation (Roti Roti 2008). Diagaradjane et al. (2008) reported that gold nanospheres induced hyperthermia in tumor upon laser irradiation. The tumor perfusion increased, resulting in fewer hypoxic regions. As a result, the tumor response to radiotherapy was significantly enhanced: the tumor doubling time was 29 days for the combination therapy group, compared to 17 days for the radiation monotherapy group. Atkinson et al. (2010) discovered that gold nanosphere-mediated hypothermia depleted the population of breast cancer stem cells. While radiation monotherapy enriched the cancer stem cells by $30 \%$, the combination therapy with hyperthermia reduced their population by more than $70 \%$. Histological analysis also revealed that the combination therapy-treated tumors had more differentiated phenotypes. $\mathrm{CuS}$ nanoparticles display strong absorption of nearinfrared light, which enabled the photothermal ablation therapy. We recently examined $\left[{ }^{64} \mathrm{Cu}\right]-\mathrm{CuS}$ nanoparticles for the dual radiotherapy (by $\beta$ emission from ${ }^{64} \mathrm{Cu}$ ) and photothermal therapy against 4T1 breast cancer model (Zhou et al. 2015b). Photothermal therapy decreased the number of tumor mammospheres, indicating the tumor-initiating cells were depleted by photothermal therapy. In vivo animal study showed that combined photothermal therapy and radiotherapy mediated by $\left[{ }^{64} \mathrm{Cu}\right]-\mathrm{CuS}$ induced better anti-tumor activity than either photothermal therapy (mediated by $\mathrm{CuS}$ nanoparticles plus near-infrared laser) or radiotherapy (mediated by $\left[{ }^{64} \mathrm{Cu}\right]-\mathrm{CuS}$ nanoparticles) alone, as judged by significantly reduced number of lung metastasis nodules and prolonged survival of mice bearing orthotopic 4T1 breast tumor.

\section{Conclusions and future perspectives}

We have reviewed the application of nanoparticles for internal radiotherapy and radiosensitization. One of the key premises of nanoparticles is to deposit as much radiation energy as possible to tumor and make tumor as vulnerable as possible to radiotherapy. Another basic feature of nanoparticles is their multi-functionality and the capability to enable multimodality therapy directed to the same treatment volume at the same time. It is expected that nanoparticle-based radiotherapy will make significant contributions to cancer treatment when successfully translated into the clinic. However, success in combining nanomedicine and radiotherapy in the clinic will require advances in multiple fronts. First, the tumor-specific accumulation of nanoparticles is still far from being ideal, with a majority of the injected dose in most nano-carriers being sequestered in organs of the mononuclear phagocytic system. Future studies are needed to direct more efforts toward developing nanoparticle systems with minimal retention in the body 
after radiotherapy is over. Second, reproducible large-scale production processes must be developed and implemented under good manufacturing practice (GMP) guidelines. In addition, the biosafety profiles of nanoparticles must be determined using the GMP products. These studies are often time-consuming and resource-intensive, and have become the bottleneck for clinical translation of any nanoparticle-based therapeutic agent. Radiolabeled nanoparticles for internal radiotherapy add another dimension of complexity, because radiolabeling often needs to be completed in short time while keeping a satisfactory labeling efficiency and radiostability. The dosimetry of radiolabeled nanoparticles also needs to be adequately determined to estimate potential radiation exposure to normal organs.

\section{Authors' contributions}

JZ drafted the manuscript. MZ participated in the preparation of a section of the manuscript. CL designed, coordinated, and helped structure the content of the manuscript. All authors read and approved the final manuscript.

\section{Author details \\ 1 Department of Cancer Systems Imaging, The University of Texas MD Anderson Cancer Center, 1881 East Road, Houston, TX 77054, USA. ${ }^{2}$ Present Address: Institute of Translational Medicine, Zhejiang University, Hangzhou, 310009 Zhejiang, China.}

\section{Acknowledgements}

This work was supported in part by the Viragh Family Foundation and the John S. Dunn Foundation. Imaging study was conducted at the MD Anderson Center for Advanced Biomedical Imaging in part with equipment support from General Electric Healthcare.

\section{Competing interests}

The authors declare that they have no competing interests.

Received: 9 June 2016 Accepted: 2 November 2016

Published online: 16 November 2016

\section{References}

Allison RR, Downie GH, Cuenca R, Hu XH, Childs CJ, Sibata CH. Photosensitizers in clinical PDT. Photodiagn Photodyn Ther 2004; $1: 27-42$

Alqathami M, Blencowe A, Yeo UJ, Franich R, Doran S, Qiao G, Geso M. Enhancement of radiation effects by bismuth oxide nanoparticles for kilovoltage $X$-ray beams: a dosimetric study using a novel multi-compartment 3D radiochromic dosimeter. J Phys Conf Ser. 2013;444:012025.

Anderson CJ, Welch MJ. Radiometal-labeled agents (non-technetium) for diagnostic imaging. Chem Rev. 1999;99:2219-34.

Ando A, Ando I, Hiraki T, Hisada K. Relation between the location of elements in the periodic table and various organuptake rates. Nucl Med Biol. 1989;16:57-80.

Assmus A. Early history of X rays. Beam Line. 1995;25:10-24.

Atkinson RL, Zhang M, Diagaradjane P, Peddibhotla S, Contreras A, Hilsenbeck SG, Woodward WA, Krishnan S, Chang JC, Rosen JM. Thermal enhancement with optically activated gold nanoshells sensitizes breast cancer stem cells to radiation therapy. Sci Transl Med. 2010;2:55ra79.

Au KM, Min Y, Tian X, Zhang L, Perello V, Caster JM, Wang AZ. Improving cancer chemoradiotherapy treatment by dual controlled release of wortmannin and docetaxel in polymeric nanoparticles. ACS Nano. 2015;9:8976-96.

Bao A, Goins B, Klipper R, Negrete G, Mahindaratne M, Phillips WT. A novel liposome radiolabeling method using 99mTc"SNS/S" complexes: in vitro and in vivo evaluation. J Pharm Sci. 2003:92:1893-904.

Bases R, Brodie SS, Rubenfeld S. Attempts at tumor localization using Cu 64-labeled copper porphyrins. Cancer. 1958:11:259-63.

Behr TM, Behe M, Angerstein C, Gratz S, Mach R, Hagemann L, Jenner N, Stiehler M, Frank-Raue K, Raue F, Becker W. Cholecystokinin-B/gastrin receptor binding peptides: preclinical development and evaluation of their diagnostic and therapeutic potential. Clin Cancer Res. 1999;5:3124s-38s.

Black KC, Wang Y, Luehmann HP, Cai X, Xing W, Pang B, Zhao Y, Cutler CS, Wang LV, Liu Y, Xia Y. Radioactive 198Au-doped nanostructures with different shapes for in vivo analyses of their biodistribution, tumor uptake, and intratumoral distribution. ACS Nano. 2014;8:4385-94.

Boswell CA, Sun X, Niu W, Weisman GR, Wong EH, Rheingold AL, Anderson CJ. Comparative in vivo stability of copper64-labeled cross-bridged and conventional tetraazamacrocyclic complexes. J Med Chem. 2004;47:1465-74.

Browne E, Firestone RB, Shirley VS. Table of radioactive isotopes. New York: Wiley; 1986.

Bulin A-L, Truillet C, Chouikrat R, Lux F, Frochot C, Amans D, Ledoux G, Tillement O, Perriat P, Barberi-Heyob M, Dujardin C. X-ray-induced singlet oxygen activation with nanoscintillator-coupled porphyrins. J Phys Chem C. 2013;117:21583-9. 
Camera L, Kinuya S, Garmestani K, Wu C, Brechbiel MW, Pai LH, McMurry TJ, Gansow OA, Pastan I, Paik CH, et al. Evaluation of the serum stability and in vivo biodistribution of CHX-DTPA and other ligands for yttrium labeling of monoclonal antibodies. J Nucl Med. 1994;35:882-9.

Chang YJ, Chang CH, Chang TJ, Yu CY, Chen LC, Jan ML, Luo TY, Lee TW, Ting G. Biodistribution, pharmacokinetics and microSPECT/CT imaging of ${ }^{188}$ Re-bMEDA-liposome in a C26 murine colon carcinoma solid tumor animal model. Anticancer Res. 2007;27:2217-25.

Chen L, Zhong X, Yi X, Huang M, Ning P, Liu T, Ge C, Chai Z, Liu Z, Yang K. Radionuclide (131)I labeled reduced graphene oxide for nuclear imaging guided combined radio- and photothermal therapy of cancer. Biomaterials. 2015;66:21-8.

Chinnaiyan P, Vallabhaneni G, Armstrong E, Huang S-M, Harari PM. Modulation of radiation response by histone deacetylase inhibition. Int J Radiat Oncol Biol Phys. 2005;62:223-9.

Chithrani DB, Jelveh S, Jalali F, van Prooijen M, Allen C, Bristow RG, Hill RP, Jaffray DA. Gold nanoparticles as radiation sensitizers in cancer therapy. Radiat Res. 2010;173:719-28.

Christensen E, Verroust P. Megalin and cubilin, role in proximal tubule function and during development. Pediatr Nephrol. 2002:17:993-9.

Creane M, Seymour CB, Colucci S, Mothersill C. Radiobiological effects of docetaxel (Taxotere): a potential radiation sensitizer. Int J Radiat Biol. 1999;75:731-7.

Dan TL, John G, André W, Reinhard G. Ion-beam therapy. In Charged particle and photon interactions with matter. Boca Raton: CRC Press; 2003.

de Castro MAG, Bunt G, Wouters FS. Cathepsin B launches an apoptotic exit effort upon cell death-associated disruption of lysosomes. Cell Death Discov. 2016;2:16012.

de Jong M, Barone R, Krenning E, Bernard B, Melis M, Visser T, Gekle M, Willnow TE, Walrand S, Jamar F, Pauwels S. Megalin is essential for renal proximal tubule reabsorption of 111In-DTPA-Octreotide. J Nucl Med. 2005;46:1696-700.

DeNardo SJ, Denardo GL. Targeted radionuclide therapy for solid tumors: an overview. Int J Radiat Oncol Biol Phys. 2006;66:S89-95.

Deutsch E, Libson K, Vanderheyden J-L, Ketring AR, Maxon HR. Radiolabelled Monoclonal AntibodiesThe chemistry of rhenium and technetium as related to the use of isotopes of these elements in therapeutic and diagnostic nuclear medicine. Int J Radiat Appl Instrum. 1986;13:465-77.

Di Pasqua AJ, Yuan H, Chung Y, Kim JK, Huckle JE, Li C, Sadgrove M, Tran TH, Jay M, Lu X. Neutron-activatable holmiumcontaining mesoporous silica nanoparticles as a potential radionuclide therapeutic agent for ovarian cancer. J Nucl Med. 2013;54:111-6.

Diagaradjane P, Shetty A, Wang JC, Elliott AM, Schwartz J, Shentu S, Park HC, Deorukhkar A, Stafford RJ, Cho SH, Tunnell JW, Hazle JD, Krishnan S. Modulation of in vivo tumor radiation response via gold nanoshell-mediated vascularfocused hyperthermia: characterizing an integrated antihypoxic and localized vascular disrupting targeting strategy. Nano Lett. 2008;8:1492-500.

Eetezadi S, Ekdawi SN, Allen C. The challenges facing block copolymer micelles for cancer therapy: in vivo barriers and clinical translation. Adv Drug Deliv Rev. 2015;91:7-22.

Fajardo LF, Colby TV. Pathogenesis of veno-occlusive liver disease after radiation. Arch Pathol Lab Med. 1980;104:584-8.

Fatouros PP, Corwin FD, Chen ZJ, Broaddus WC, Tatum JL, Kettenmann B, Ge Z, Gibson HW, Russ JL, Leonard AP, Duchamp $\mathrm{JC}$, Dorn HC. In vitro and in vivo imaging studies of a new endohedral metallofullerene nanoparticle. Radiology. 2006;240:756-64.

Gavande NS, VanderVere-Carozza PS, Hinshaw HD, Jalal SI, Sears CR, Pawelczak KS, Turchi JJ. DNA repair targeted therapy: the past or future of cancer treatment? Pharmacol Ther. 2016;160:65-83.

Giovacchini G, Nicolas G, Forrer F. Peptide receptor radionuclide therapy with somatostatin analogues in neuroendocrine tumors. Anticancer Agents Med Chem. 2012;12:526-42.

Guo W, Sun X, Jacobson O, Yan X, Min K, Srivatsan A, Niu G, Kiesewetter DO, Chang J, Chen X. Intrinsically radioactive [64Cu]CulnS/ZnS quantum dots for PET and optical imaging: improved radiochemical stability and controllable Cerenkov luminescence. ACS Nano. 2015;9:488-95.

Hainfeld JF, Slatkin DN, Smilowitz HM. The use of gold nanoparticles to enhance radiotherapy in mice. Phys Med Biol. 2004;49:N309-15.

Hainfeld JF, Slatkin DN, Focella TM, Smilowitz HM. Gold nanoparticles: a new X-ray contrast agent. Br J Radiol. 2006;79:248-53.

Hainfeld JF, Dilmanian FA, Slatkin DN, Smilowitz HM. Radiotherapy enhancement with gold nanoparticles. J Pharm Pharmacol. 2008;60:977-85.

He L, Lai H, Chen T. Dual-function nanosystem for synergetic cancer chemo-/radiotherapy through ROS-mediated signaling pathways. Biomaterials. 2015;51:30-42.

Herold DM, Das IJ, Stobbe CC, Iyer RV, Chapman JD. Gold microspheres: a selective technique for producing biologically effective dose enhancement. Int J Radiat Biol. 2000;76:1357-64.

Huang X, Jain PK, El-Sayed IH, El-Sayed MA. Plasmonic photothermal therapy (PPTT) using gold nanoparticles. Lasers Med Sci. 2008;23:217-28.

Huang FY, Lee TW, Kao CH, Chang CH, Zhang X, Lee WY, Chen WJ, Wang SC, Lo JM. Imaging, autoradiography, and biodistribution of (188)Re-labeled PEGylated nanoliposome in orthotopic glioma bearing rat model. Cancer Biother Radiopharm. 2011;26:717-25.

Huang Y, Luo Y, Zheng W, Chen T. Rational design of cancer-targeted BSA protein nanoparticles as radiosensitizer to overcome cancer radioresistance. ACS Appl Mater Interfaces. 2014;6:19217-28.

Jeremic B, Aguerri AR, Filipovic N. Radiosensitization by gold nanoparticles. Clin Transl Oncol. 2013;15:593-601.

Jung J, Park SJ, Chung HK, Kang HW, Lee SW, Seo MH, Park HJ, Song SY, Jeong SY, Choi EK. Polymeric nanoparticles containing taxanes enhance chemoradiotherapeutic efficacy in non-small cell lung cancer. Int J Radiat Oncol Biol Phys. 2012;84:e77-83.

Kamiar A, Ghotalou R, Vali Zadeh H. Preparation, physicochemical characterization and performance evaluation of gold nanoparticles in radiotherapy. Adv Pharm Bull. 2013;3:425-8. 
Kassis Al. The amazing world of auger electrons. Taylor \& Francis: Routledge; 2004.

Kavanagh JN, Redmond KM, Schettino G, Prise KM. DNA double strand break repair: a radiation perspective. Antioxid Redox Signal. 2013;18:2458-72.

Ke S, Milas L, Charnsangavej C, Wallace S, Li C. Potentiation of radioresponse by polymer-drug conjugates. J Control Release. 2001;74:237-42.

Kennedy A. Radioembolization of hepatic tumors. J Gastrointest Oncol. 2014;5:178-89.

Kobayashi K, Usami N, Porcel E, Lacombe S, Le Sech C. Enhancement of radiation effect by heavy elements. Mutat Res/ Rev Mutat Res. 2010;704:123-31.

Kryza D, Taleb J, Janier M, Marmuse L, Miladi I, Bonazza P, Louis C, Perriat P, Roux S, Tillement O, Billotey C. Biodistribution study of nanometric hybrid gadolinium oxide particles as a multimodal SPECT/MR/optical imaging and theragnostic agent. Bioconjugate Chem. 2011:22:1145-52.

Langen B, Rudqvist N, Parris TZ, Schüler E, Spetz J, Helou K, Forssell-Aronsson E. Transcriptional response in normal mouse tissues after i.v. (211) At administration — response related to absorbed dose, dose rate, and time. EJNMMI Res. 2015;5:1.

Lawrence TS, Robertson JM, Anscher MS, Jirtle RL, Ensminger WD, Fajardo LF. Hepatic toxicity resulting from cancer treatment. Int J Radiat Oncol Biol Phys. 1995;31:1237-48.

Le Duc G, Miladi I, Alric C, Mowat P, Bräuer-Krisch E, Bouchet A, Khalii E, Billotey C, Janier M, Lux F, Epicier T, Perriat P, Roux $\mathrm{S}$, Tillement $\mathrm{O}$. Toward an image-guided microbeam radiation therapy using gadolinium-based nanoparticles. ACS Nano. 2011;5:9566-74

Leamon CP, Low PS. Delivery of macromolecules into living cells: a method that exploits folate receptor endocytosis. Proc Natl Acad Sci USA. 1991;88:5572-6.

Lee JH, Choy ML, Ngo L, Foster SS, Marks PA. Histone deacetylase inhibitor induces DNA damage, which normal but not transformed cells can repair. Proc Natl Acad Sci U S A. 2010;107:14639-44.

Lepareur N, Garin E, Noiret N, Herry JY. A kit formulation for the labelling of lipiodol with generator-produced 188Re. J Label Compd Radiopharm. 2004;47:857-67.

Lewin K, Millis RR. Human radiation hepatitis. A morphologic study with emphasis on the late changes. Arch Pathol. 1973:96:21-6.

Li C. A targeted approach to cancer imaging and therapy. Nat Mater. 2014;13:110-5.

Li M, Meares CF, Zhong G-R, Miers L, Xiong C-Y, DeNardo SJ. Labeling monoclonal antibodies with ${ }^{90}$ Yttrium- and ${ }^{111}$ Indium-DOTA chelates: a simple and efficient method. Bioconjug Chem. 1994;5:101-4.

Li C, Ke S, Wu QP, Tansey W, Hunter N, Buchmiller LM, Milas L, Charnsangavej C, Wallace S. Potentiation of ovarian OCa-1 tumor radioresponse by poly (L-glutamic acid)-paclitaxel conjugate. Int J Radiat Oncol Biol Phys. 2000a:48:1119-26.

Li C, Ke S, Wu QP, Tansey W, Hunter N, Buchmiller LM, Milas L, Charnsangavej C, Wallace S. Tumor irradiation enhances the tumor-specific distribution of poly(L-glutamic acid)-conjugated paclitaxel and its antitumor efficacy. Clin Cancer Res. 2000b;6:2829-34.

Li T, Zhang M, Wang J, Wang T, Yao Y, Zhang X, Zhang C, Zhang N. Thermosensitive hydrogel co-loaded with gold nanoparticles and doxorubicin for effective chemoradiotherapy. AAPS J. 2015;18:146-55. doi:10.1208/ s12248-015-9828-3.

Li J, Wang R, Schweickert PG, Karki A, Yang Y, Kong Y, Ahmad N, Konieczny SF, Liu X. PIk1 inhibition enhances the efficacy of gemcitabine in human pancreatic cancer. Cell Cycle. 2016;15:711-9.

Lin LT, Chang CH, Yu HL, Liu RS, Wang HE, Chiu SJ, Chen FD, Lee TW, Lee YJ. Evaluation of the therapeutic and diagnostic effects of PEGylated liposome-embedded ${ }^{188}$ Re on human non-small cell lung cancer using an orthotopic smallanimal model. J Nucl Med. 2014:55:1864-70.

Lin Y, Paganetti H, McMahon SJ, Schuemann J. Gold nanoparticle induced vasculature damage in radiotherapy: comparing protons, megavoltage photons, and kilovoltage photons. Med Phys. 2015:42:5890.

Liu S. Bifunctional coupling agents for radiolabeling of biomolecules and target-specific delivery of metallic radionuclides. Adv Drug Deliv Rev. 2008;60:1347-70.

Liu C, Mi CC, Li BQ. Energy absorption of gold nanoshells in hyperthermia therapy. IEEE Trans Nanobiosci. 2008;7:206-14.

Liu TW, Macdonald TD, Jin CS, Gold JM, Bristow RG, Wilson BC, Zheng G. Inherently multimodal nanoparticle-driven tracking and real-time delineation of orthotopic prostate tumors and micrometastases. ACS Nano. 2013;7:4221-32.

Liu T, Shi S, Liang C, Shen S, Cheng L, Wang C, Song X, Goel S, Barnhart TE, Cai W, Liu Z. Iron oxide decorated MoS 2 nanosheets with double PEGylation for chelator-free radiolabeling and multimodal imaging guided photothermal therapy. ACS Nano. 2015a;9:950-60.

Liu J, Liang Y, Liu T, Li D, Yang X. Anti-EGFR-conjugated hollow gold nanospheres enhance radiocytotoxic targeting of cervical cancer at megavoltage radiation energies. Nanoscale Res Lett. 2015b;10:218.

Lord CJ, Ashworth A. The DNA damage response and cancer therapy. Nature. 2012;481:287-94.

Ma M, Huang Y, Chen H, Jia X, Wang S, Wang Z, Shi J. $\mathrm{Bi}_{2} \mathrm{~S}_{3}$-embedded mesoporous silica nanoparticles for efficient drug delivery and interstitial radiotherapy sensitization. Biomaterials. 2015;37:447-55.

Mah LJ, Vasireddy RS, Tang MM, Georgiadis GT, El-Osta A, Karagiannis TC. Quantification of H2AX foci in response to ionising radiation. JoVE. 2010. doi:10.3791/1957.

Matsudaira H, Ueno AM, Furuno I. Iodine contrast medium sensitizes cultured mammalian cells to $X$ rays but not to $\gamma$ rays. Radiat Res. 1980;84:144-8.

McQuaid HN, Muir MF, Taggart LE, McMahon SJ, Coulter JA, Hyland WB, Jain S, Butterworth KT, Schettino G, Prise KM, Hirst DG, Botchway SW, Currell FJ. Imaging and radiation effects of gold nanoparticles in tumour cells. Sci Rep. 2016:6:19442.

Melancon MP, Zhou M, Li C. Cancer theranostics with near-infrared light-activatable multimodal nanoparticles. Acc Chem Res. 2011:44:947-56.

Miladi I, Duc GL, Kryza D, Berniard A, Mowat P, Roux S, Taleb J, Bonazza P, Perriat P, Lux F, Tillement O, Billotey C, Janier M. Biodistribution of ultra small gadolinium-based nanoparticles as theranostic agent: application to brain tumors.J Biomater Appl. 2013;28:385-94. 
Miladi I, Aloy MT, Armandy E, Mowat P, Kryza D, Magne N, Tillement O, Lux F, Billotey C, Janier M, Rodriguez-Lafrasse C. Combining ultrasmall gadolinium-based nanoparticles with photon irradiation overcomes radioresistance of head and neck squamous cell carcinoma. Nanomedicine. 2015;11:247-57.

Milas L, Mason KA, Hunter N, Li C, Wallace S. Poly(L-glutamic acid)-paclitaxel conjugate is a potent enhancer of tumor radiocurability. Int J Radiat Oncol Biol Phys. 2003;55:707-12.

Moll S, Nickeleit V, Mueller-Brand J, Brunner FP, Maecke HR, Mihatsch MJ. A new cause of renal thrombotic microangiopathy: yttrium 90-DOTATOC internal radiotherapy. Am J Kidney Dis. 2001;37:847-51.

Mozumder A. Interaction of fast charged particles with matter. In Charged particle and photon interactions with matter. Boca Raton: CRC Press; 2003.

Munaweera I, Shi Y, Koneru B, Saez R, Aliev A, Di Pasqua AJ, Balkus KJ Jr. Chemoradiotherapeutic magnetic nanoparticles for targeted treatment of nonsmall cell lung cancer. Mol Pharm. 2015;12:3588-96.

Muralidharan P, Malapit M, Mallory E, Hayes D Jr, Mansour HM. Inhalable nanoparticulate powders for respiratory delivery. Nanomedicine. 2015;11:1189-99.

Nilsson R, Eriksson SE, Sjogren HO, Tennvall J. Different toxicity profiles for drug-versus radionuclide-conjugated BR96 monoclonal antibodies in a syngeneic rat colon carcinoma model. Acta Oncol. 2011;50:711-8.

O'Connor AE, Gallagher WM, Byrne AT. Porphyrin and nonporphyrin photosensitizers in oncology: preclinical and clinical advances in photodynamic therapy. Photochem Photobiol. 2009;85:1053-74.

Oh E, Delehanty JB, Sapsford KE, Susumu K, Goswami R, Blanco-Canosa JB, Dawson PE, Granek J, Shoff M, Zhang Q, Goering PL, Huston A, Medintz IL. Cellular uptake and fate of PEGylated gold nanoparticles is dependent on both cell-penetration peptides and particle size. ACS Nano. 2011;5:6434-48.

Oldenburg SJ, Averitt RD, Westcott SL, Halas NJ. Nanoengineering of optical resonances. Chem Phys Lett. 1998;288:243-7.

Pazdur R, Kudelka AP, Kavanagh JJ, Cohen PR, Raber MN. The taxoids: paclitaxel (Taxol) and docetaxel (Taxotere). Cancer Treat Rev. 1993;19:351-86.

Phaeton R, Jiang Z, Revskaya E, Fisher DR, Goldberg GL, Dadachova E. Beta emitters rhenium-188 and lutetium-177 are equally effective in radioimmunotherapy of HPV-positive experimental cervical cancer. Cancer Med. 2016;5:9-16.

Phillips WT, Bao A, Brenner AJ, Goins BA. Image-guided interventional therapy for cancer with radiotherapeutic nanoparticles. Adv Drug Deliv Rev. 2014;76:39-59.

Pimm MV, Gribben SJ. Prevention of renal tubule re-absorption of radiometal (indium-111) labelled Fab fragment of a monoclonal antibody in mice by systemic administration of lysine. Eur J Nucl Med Mol Imaging. 1994;21:663-5.

Pohlman B, Sweetenham J, Macklis RM. Review of clinical radioimmunotherapy. Expert Rev Anticancer Ther. 2006:6:445-61.

Pollom EL, Deng L, Pai RK, Brown JM, Giaccia A, Loo BW, Shultz DB Jr, Le QT, Koong AC, Chang DT. Gastrointestinal toxicities with vombined antiangiogenic and stereotactic body radiation therapy. Int J Radiat Oncol Biol Phys. 2015;92:568-76.

Porcel E, Liehn S, Remita H, Usami N, Kobayashi K, Furusawa Y, Le Sech C, Lacombe S. Platinum nanoparticles: a promising material for future cancer therapy? Nanotechnology. 2010;21:85103.

Prasad P, Gordijo CR, Abbasi AZ, Maeda A, Ip A, Rauth AM, Dacosta RS, Wu XY. Multifunctional albumin- $\mathrm{MnO}_{2}$ nanoparticles modulate solid tumor microenvironment by attenuating hypoxia, acidosis, vascular endothelial growth factor and enhance radiation response. ACS Nano. 2014;8:3202-12.

Rabi T, Bishayee A. d -Limonene sensitizes docetaxel-induced cytotoxicity in human prostate cancer cells: generation of reactive oxygen species and induction of apoptosis. J Carcinog. 2009;8:9.

Radovic M, Calatayud MP, Goya GF, Ibarra MR, Antic B, Spasojevic V, Nikolic N, Jankovic D, Mirkovic M, Vranjes-Duric S. Preparation and in vivo evaluation of multifunctional (9)(0)Y-labeled magnetic nanoparticles designed for cancer therapy. J Biomed Mater Res A. 2015;103:126-34.

Rahman WN, Corde S, Yagi N, Abdul Aziz SA, Annabell N, Geso M. Optimal energy for cell radiosensitivity enhancement by gold nanoparticles using synchrotron-based monoenergetic photon beams. Int J Nanomed. 2014;9:2459-67.

Retif P, Pinel S, Toussaint M, Frochot C, Chouikrat R, Bastogne T, Barberi-Heyob M. Nanoparticles for radiation therapy enhancement: the key parameters. Theranostics. 2015;5:1030-44.

Rima W, Sancey L, Aloy M-T, Armandy E, Alcantara GB, Epicier T, Malchère A, Joly-Pottuz L, Mowat P, Lux F, Tillement O, Burdin B, Rivoire A, Boulé C, Anselme-Bertrand I, Pourchez J, Cottier M, Roux S, Rodriguez-Lafrasse C, Perriat P. Internalization pathways into cancer cells of gadolinium-based radiosensitizing nanoparticles. Biomaterials. 2013;34:181-95.

Roa W, Zhang X, Guo L, Shaw A, Hu X, Xiong Y, Gulavita S, Patel S, Sun X, Chen J, Moore R, Xing JZ. Gold nanoparticle sensitize radiotherapy of prostate cancer cells by regulation of the cell cycle. Nanotechnology. 2009;20:375101.

Roti Roti JL. Cellular responses to hyperthermia (40-46 degrees C): cell killing and molecular events. Int J Hyperthermia. 2008;24:3-15.

Russo A, Pagliara V, Albano F, Esposito D, Sagar V, Loreni F, Irace C, Santamaria R, Russo G. Regulatory role of rpL3 in cell response to nucleolar stress induced by Act D in tumor cells lacking functional p53. Cell Cycle. 2016;15:41-51.

Samuelian JM, Callister MD, Ashman JB, Young-Fadok TM, Borad MJ, Gunderson LL. Reduced acute bowel toxicity in patients treated with intensity-modulated radiotherapy for rectal cancer. Int J Radiat Oncol Biol Phys. 2012;82:1981-7.

Sancey L, Lux F, Kotb S, Roux S, Dufort S, Bianchi A, Cremillieux Y, Fries P, Coll JL, Rodriguez-Lafrasse C, Janier M, Dutreix M, Barberi-Heyob M, Boschetti F, Denat F, Louis C, Porcel E, Lacombe S, Le Duc G, Deutsch E, Perfettini JL, Detappe A, Verry C, Berbeco R, Butterworth KT, McMahon SJ, Prise KM, Perriat P, Tillement O. The use of theranostic gadolinium-based nanoprobes to improve radiotherapy efficacy. Br J Radiol. 2014;87:20140134.

Schuemann J, Berbeco R, Chithrani DB, Cho SH, Kumar R, McMahon SJ, Sridhar S, Krishnan S. Roadmap to clinical use of gold nanoparticles for radiation sensitization. Int J Radiat Oncol Biol Phys. 2016;94:189-205.

Seevinck PR, Seppenwoolde J-H, de Wit TC, Nijsen W, Johannes F, Beekman FJ, van het Schip AD, Beekman FJ, Bakker G, Chris J. Factors affecting the sensitivity and detection limits of MRI, CT, and SPECT for multimodal diagnostic and therapeutic agents. Anticancer Agents Med Chem. 2007;7:317-34.

Sgouros G. Dosimetry of internal emitters. Nano Lett. 2005;46(Suppl 1):18S-27S. 
Shaffer TM, Wall MA, Harmsen S, Longo VA, Drain CM, Kircher MF, Grimm J. Silica nanoparticles as substrates for chelatorfree labeling of oxophilic radioisotopes. Int J Radiat Oncol Biol Phys. 2015;15:864-8.

Sicard-Roselli C, Brun E, Gilles M, Baldacchino G, Kelsey C, McQuaid H, Polin C, Wardlow N, Currell F. A new mechanism for hydroxyl radical production in irradiated nanoparticle solutions. Small. 2014;10:3338-46.

Sinha N, Cifter G, Sajo E, Kumar R, Sridhar S, Nguyen PL, Cormack RA, Makrigiorgos GM, Ngwa W. Brachytherapy application with in situ dose painting administered by gold nanoparticle eluters. Int J Radiat Oncol Biol Phys. 2015:91:385-92

Smith BE, Gouterman M. Quartet luminescence from copper porphyrins. Chem Phys Lett. 1968;2:517-9.

Snyder WS, Fisher HL, Ford MR Jr, Warner GG. Estimates of absorbed fractions for monoenergetic photon sources uniformly distributed in various organs of a heterogeneous phantom. J Nucl Med, Suppl. 1969;3:7-52.

Song G, Liang C, Gong H, Li M, Zheng X, Cheng L, Yang K, Jiang X, Liu Z. Core-shell MnSe@Bi $\mathrm{Se}_{3}$ fabricated via a cation exchange method as novel nanotheranostics for multimodal imaging and synergistic thermoradiotherapy. Adv Mater. 2015;27:6110-7.

Stahl AR, Wagner B, Poethko T, Perutka M, Wester HJ, Essler M, Heemann U, Schwaiger M, Lutz J. Renal accumulation of [111 In]DOTATOC in rats: influence of inhibitors of the organic ion transport and diuretics. Eur J Nucl Med Mol Imaging. 2007;34:2129-34.

Stefancikova L, Porcel E, Eustache P, Li S, Salado D, Marco S, Guerquin-Kern JL, Refregiers M, Tillement O, Lux F, Lacombe S. Cell localisation of gadolinium-based nanoparticles and related radiosensitising efficacy in glioblastoma cells. Cancer Nanotechnol. 2014;5:6.

Subiel A, Ashmore R, Schettino G. Standards and methodologies for characterizing radiobiological impact of high-Z nanoparticles. Theranostics. 2016;6:1651-71.

Sun X, Huang X, Guo J, Zhu W, Ding Y, Niu G, Wang A, Kiesewetter DO, Wang ZL, Sun S, Chen X. Self-illuminating ${ }^{64} \mathrm{Cu}$ doped CdSe/Zns nanocrystals for in vivo tumor imaging. J Am Chem Soc. 2014a;136:1706-9.

Sun X, Huang X, Yan X, Wang Y, Guo J, Jacobson O, Liu D, Szajek LP, Zhu W, Niu G, Kiesewetter DO, Sun S, Chen X. Chelatorfree (64)Cu-integrated gold nanomaterials for positron emission tomography imaging guided photothermal cancer therapy. ACS Nano. 2014b;8:8438-46.

Svensson J, Molne J, Forssell-Aronsson E, Konijnenberg M, Bernhardt P. Nephrotoxicity profiles and threshold dose values for [177Lu]-DOTATATE in nude mice. Nucl Med Biol. 2012;39:756-62.

Uehara T, Koike M, Nakata H, Hanaoka H, lida Y, Hashimoto K, Akizawa H, Endo K, Arano Y. Design, synthesis, and evaluation of [188Re]organorhenium-labeled antibody fragments with renal enzyme-cleavable linkage for low renal radioactivity levels. Bioconj Chem. 2007;18:190-8.

Usami N, Furusawa Y, Kobayashi K, Frohlich H, Lacombe S, Le Sech C. Fast He2+ ion irradiation of DNA loaded with platinum-containing molecules. Int J Radiat Biol. 2005:81:515-22.

Usami N, Kobayashi K, Furusawa Y, Frohlich H, Lacombe S, Sech CL. Irradiation of DNA loaded with platinum containing molecules by fast atomic ions $C(6+)$ and Fe(26+). Int J Radiat Biol. 2007;83:569-76.

Usami N, Furusawa Y, Kobayashi K, Lacombe S, Reynaud-Angelin A, Sage E, Wu TD, Croisy A, Guerquin-Kern JL, Le Sech C. Mammalian cells loaded with platinum-containing molecules are sensitized to fast atomic ions. Int J Radiat Biol. 2008;84:603-11.

Usami N, Kobayashi K, Hirayama R, Furusawa Y, Porcel E, Lacombe S, Le Sech C. Comparison of DNA breaks at entrance channel and Bragg peak induced by fast C $6+$ ions-influence of the addition of platinum atoms on DNA.J Radiat Res. 2010;51:21-6.

Valkema R, Pauwels SA, Kvols LK, Kwekkeboom DJ, Jamar F, de Jong M, Barone R, Walrand S, Kooij PP, Bakker WH, Lasher J, Krenning EP. Long-term follow-up of renal function after peptide receptor radiation therapy with (90)Y-DOTA(0), Tyr(3)-octreotide and (177)Lu-DOTA(0), Tyr(3)-octreotate. J Nucl Med. 2005;46(Suppl 1):83S-91S.

van Essen M, Krenning EP, Kam BLR, de Jong M, Valkema R, Kwekkeboom DJ. Peptide-receptor radionuclide therapy for endocrine tumors. Nature Rev Endocrinol. 2009;5:382-93.

Vanpouille-Box C, Lacoeuille F, Belloche C, Lepareur N, Lemaire L, LeJeune JJ, Benoit JP, Menei P, Couturier OF, Garcion E, Hindre F. Tumor eradication in rat glioma and bypass of immunosuppressive barriers using internal radiation with (188)Re-lipid nanocapsules. Biomaterials. 2011;32:6781-90.

Vaupel P, Schlenger K, Knoop C, Höckel M. Oxygenation of human tumors: evaluation of tissue oxygen distribution in breast cancers by computerized $\mathrm{O}_{2}$ tension measurements. Cancer Res. 1991;51:3316-22.

Vaupel P, Thews O, Hoeckel M. Treatment resistance of solid tumors: role of hypoxia and anemia. Med Oncol. 2001;18:243-59.

Vegt E, de Jong M, Wetzels JF, Masereeuw R, Melis M, Oyen WJ, Gotthardt M, Boerman OC. Renal toxicity of radiolabeled peptides and antibody fragments: mechanisms, impact on radionuclide therapy, and strategies for prevention. J Nucl Med. 2010;51:1049-58.

Villard L, Romer A, Marincek N, Brunner P, Koller MT, Schindler C, Ng QK, Macke HR, Muller-Brand J, Rochlitz C, Briel M, Walter MA. Cohort study of somatostatin-based radiopeptide therapy with [(90)Y-DOTA]-TOC versus [(90)Y-DOTA]-TOC plus [(177)Lu-DOTA]-TOC in neuroendocrine cancers. J Clin Oncol. 2012;30:1100-6.

Wang L, Yang W, Read P, Larner J, Sheng K. Tumor cell apoptosis induced by nanoparticle conjugate in combination with radiation therapy. Nanotechnology. 2010;21:475103.

Wang C, Jiang Y, Li X, Hu L. Thioglucose-bound gold nanoparticles increase the radiosensitivity of a triple-negative breast cancer cell line (MDA-MB-231). Breast Cancer. 2015a;22:413-20.

Wang EC, Min Y, Palm RC, Fiordalisi JJ, Wagner KT, Hyder N, Cox AD, Caster JM, Tian X, Wang AZ. Nanoparticle formulations of histone deacetylase inhibitors for effective chemoradiotherapy in solid tumors. Biomaterials. 2015b;51:208-15.

Werner ME, Karve S, Sukumar R, Cummings ND, Copp JA, Chen RC, Zhang T, Wang AZ. Folate-targeted nanoparticle delivery of chemo- and radiotherapeutics for the treatment of ovarian cancer peritoneal metastasis. Biomaterials. 2011;32:8548-54.

Werner ME, Cummings ND, Sethi M, Wang EC, Sukumar R, Moore DT, Wang AZ. Preclinical evaluation of Genexol-PM, a nanoparticle formulation of paclitaxel, as a novel radiosensitizer for the treatment of non-small cell lung cancer. Int J Radiat Oncol Biol Phys. 2013;86:463-8. 
Wieringa HW, van der Zee AG, de Vries EG, van Vugt MA. Breaking the DNA damage response to improve cervical cancer treatment. Cancer Treat Rev. 2016;42:30-40.

Wilson JD, Broaddus WC, Dorn HC, Fatouros PP, Chalfant CE, Shultz MD. Metallofullerene-nanoplatform-delivered interstitial brachytherapy improved survival in a murine model of glioblastoma multiforme. Bioconjug Chem. 2012;23:1873-80.

Wipf P, Halter RJ. Chemistry and biology of wortmannin. Org Biomol Chem. 2005;3:2053-61.

Xiao Q, Zheng X, Bu W, Ge W, Zhang S, Chen F, Xing H, Ren Q, Fan W, Zhao K, Hua Y, Shi J. A core/satellite multifunctional nanotheranostic for in vivo imaging and tumor eradication by radiation/photothermal synergistic therapy. J Am Chem Soc. 2013;135:13041-8.

Yamada A, Traboulsi A, Dittert LW, Hussain AA. Chloramine-T in radiolabeling techniques. iii. Radioiodination of biomolecules containing thioether groups. Anal Biochem. 2000;277:232-5.

Yang K, Wan J, Zhang S, Zhang Y, Lee ST, Liu Z. In vivo pharmacokinetics, long-term biodistribution, and toxicology of PEGylated graphene in mice. ACS Nano. 2011;5:516-22.

Yao MH, Ma M, Chen Y, Jia XQ, Xu G, Xu HX, Chen HR, Wu R. Multifunctional Bi $2 \mathrm{~S}_{3} /$ PLGA nanocapsule for combined HIFU/ radiation therapy. Biomaterials. 2014;35:8197-205.

You J, Zhao J, Wen X, Wu C, Huang Q, Guan F, Wu R, Liang D, Li C. Chemoradiation therapy using cyclopamine-loaded liquid-lipid nanoparticles and lutetium-177-labeled core-crosslinked polymeric micelles. J Controll Release. 2015;202:40-8.

Zelasko-Leon DC, Fuentes CM, Messersmith PB. MUC1-targeted cancer cell photothermal ablation using bioinspired gold nanorods. PLoS ONE. 2015;10:e0128756.

Zhang XD, Wu D, Shen X, Chen J, Sun YM, Liu PX, Liang XJ. Size-dependent radiosensitization of PEG-coated gold nanoparticles for cancer radiation therapy. Biomaterials. 2012;33:6408-19.

Zhang XD, Chen J, Luo Z, Wu D, Shen X, Song SS, Sun YM, Liu PX, Zhao J, Huo S, Fan S, Fan F, Liang XJ, Xie J. Enhanced tumor accumulation of sub-2 $\mathrm{nm}$ gold nanoclusters for cancer radiation therapy. Advanced Healthcare Materials. 2014;3:133-41.

Zhang XD, Luo Z, Chen J, Song S, Yuan X, Shen X, Wang H, Sun Y, Gao K, Zhang L, Fan S, Leong DT, Guo M, Xie J. Ultrasmall glutathione-protected gold nanoclusters as next generation radiotherapy sensitizers with high tumor uptake and high renal clearance. Sci Rep. 2015a;5:8669.

Zhang C, Zhao K, Bu W, Ni D, Liu Y, Feng J, Shi J. Marriage of scintillator and semiconductor for synchronous radiotherapy and deep photodynamic therapy with diminished oxygen dependence. Angew Chem Int Ed Engl. 2015b;54:1770-4.

Zhao J, Wu C, Abbruzzese J, Hwang RF, Li C. Cyclopamine-loaded core-cross-linked polymeric micelles enhance radiation response in pancreatic cancer and pancreatic stellate cells. Mol Pharm. 2015;12:2093-100.

Zheng Y, Hunting DJ, Ayotte P, Sanche L. Radiosensitization of DNA by gold nanoparticles irradiated with high-energy electrons. Radiat Res. 2008;169:19-27.

Zhou M, Zhang R, Huang M, Lu W, Song S, Melancon MP, Tian M, Liang D, Li C. A chelator-free multifunctional [64Cu]CuS nanoparticle platform for simultaneous micro-PET/CT imaging and photothermal ablation therapy. J Am Chem Soc. 2010;132:15351-8.

Zhou M, Chen Y, Adachi M, Wen X, Erwin B, Mawlawi O, Lai SY, Li C. Single agent nanoparticle for radiotherapy and radiophotothermal therapy in anaplastic thyroid cancer. Biomaterials. 2015a;57:41-9.

Zhou M, Zhao J, Tian M, Song S, Zhang R, Gupta S, Tan D, Shen H, Ferrari M, Li C. Radio-photothermal therapy mediated by a single compartment nanoplatform depletes tumor initiating cells and reduces lung metastasis in the orthotopic 4T1 breast tumor model. Nanoscale. 2015b;7:19438-47.

Zhu H, Yan H, Jin W, Dai C, Chen Z, Zheng F, Chen X. The staining patterns of 53BP1 nuclear foci and 53BP1 mRNA level are associated with cervical cancer progression and metastasis. Int J Gynecol Pathol. 2014;33:241-7.

Zoller F, Eisenhut M, Haberkorn U, Mier W. Endoradiotherapy in cancer treatment-basic concepts and future trends. Eur J Pharmacol. 2009;625:55-62.

\section{Submit your manuscript to a SpringerOpen ${ }^{\circ}$ journal and benefit from:}

- Convenient online submission

- Rigorous peer review

Immediate publication on acceptance

- Open access: articles freely available online

- High visibility within the field

- Retaining the copyright to your article

Submit your next manuscript at $>$ springeropen.com 